\title{
Unexpected Lack of Deleterious Effects of Uranium on Physiological Systems following a Chronic Oral Intake in Adult Rat
}

\author{
Isabelle Dublineau, ${ }^{1}$ Maâmar Souidi, ${ }^{1}$ Yann Gueguen, ${ }^{1}$ Philippe Lestaevel, ${ }^{1}$ \\ Jean-Marc Bertho, ${ }^{1}$ Line Manens, ${ }^{1}$ Olivia Delissen, ${ }^{2}$ Stéphane Grison, ${ }^{1}$ \\ Anaïs Paulard, ${ }^{1}$ Audrey Monin, ${ }^{1}$ Yseult Kern, ${ }^{1}$ Caroline Rouas, ${ }^{1}$ Jeanne Loyen, ${ }^{3}$ \\ Patrick Gourmelon, ${ }^{4}$ and Jocelyne Aigueperse ${ }^{4}$ \\ ${ }^{1}$ Institut de Radioprotection et de Sûreté Nucléaire (IRSN), PRP-HOM, SRBE, LRTOX, 31 avenue de la Division Leclerc, BP 17, \\ 92262 Fontenay-aux-Roses Cedex, France \\ ${ }^{2}$ Institut de Radioprotection et de Sûreté Nucléaire (IRSN), PRP-HOM, SRBE, LRTOX, BP 166, 26702 Pierrelatte Cedex, France \\ ${ }^{3}$ Institut de Radioprotection et de Sûreté Nucléaire (IRSN), PRP-ENV, STEME, BP 40035, 78116 Le Vésinet Cedex, France \\ ${ }^{4}$ Institut de Radioprotection et de Sûreté Nucléaire (IRSN), PRP-HOM, BP 17, 92262 Fontenay-aux-Roses Cedex, France
}

Correspondence should be addressed to Isabelle Dublineau; isabelle.dublineau@irsn.fr

Received 19 September 2013; Revised 18 December 2013; Accepted 18 December 2013; Published 12 February 2014

Academic Editor: Fernando Barbosa Jr

Copyright (C) 2014 Isabelle Dublineau et al. This is an open access article distributed under the Creative Commons Attribution License, which permits unrestricted use, distribution, and reproduction in any medium, provided the original work is properly cited.

\begin{abstract}
Uranium level in drinking water is usually in the range of microgram-per-liter, but this value may be as much as 100 to 1000 times higher in some areas, which may raise question about the health consequences for human populations living in these areas. Our purpose was to improve knowledge of chemical effects of uranium following chronic ingestion. Experiments were performed on rats contaminated for 9 months via drinking water containing depleted uranium $(0.2,2,5,10,20,40$, or $120 \mathrm{mg} / \mathrm{L})$. Blood biochemical and hematological indicators were measured and several different types of investigations (molecular, functional, and structural) were conducted in organs (intestine, liver, kidneys, hematopoietic cells, and brain). The specific sensitivity of the organs to uranium was deduced from nondeleterious biological effects, with the following thresholds (in $\mathrm{mg} / \mathrm{L}$ ): 0.2 for brain, $>2$ for liver, $>10$ for kidneys, and $>20$ for intestine, indicating a NOAEL (No-Observed-Adverse-Effect Level) threshold for uranium superior to $120 \mathrm{~m} \mathrm{~g} / \mathrm{L}$. Based on the chemical uranium toxicity, the tolerable daily intake calculation yields a guideline value for humans of $1350 \mu \mathrm{g} / \mathrm{L}$. This value was higher than the WHO value of $30 \mu \mathrm{g} / \mathrm{L}$, indicating that this WHO guideline for uranium content in drinking water is very protective and might be reconsidered.
\end{abstract}

\section{Introduction}

Uranium is a natural component of the earth crust. Its concentrations vary highly according to the location and the type of rocks [1]. In fact, it can vary from 3 to $4 \mathrm{~g} / \mathrm{t}$ in granites and from 20 to $120 \mathrm{~g} / \mathrm{t}$ in phosphate rocks [2], leading consequently to a great variability of the uranium content in drinking water. For instance, average uranium levels in drinking water are in microgram-per-liter range $(0.4 \mu \mathrm{g} / \mathrm{L}$ throughout the world, [3]; $6.7 \mu \mathrm{g} / \mathrm{L}$ in USA, [4]; $4 \mu \mathrm{g} / \mathrm{L}$ in Canada [5]; $2.2 \mu \mathrm{g} / \mathrm{L}$ in China [6]; or $2.22 \mu \mathrm{g} / \mathrm{L}$ in France
[7], but they may reach exceptionally the milligram-perliter range in some specific areas, including some US states $(2.5 \mathrm{mg} / \mathrm{L}$ [4]; $7.8 \mathrm{mg} / \mathrm{L}[8])$ or southern Finland $(9.2 \mathrm{mg} / \mathrm{L}$ [9]; $3.4 \mathrm{mg} / \mathrm{L}$ [10]). Anthropogenic utilization of uranium for civil, military, and nuclear fuel purposes leads to additional release of this radio element into environment, either around uranium mining sites [11, 12], uranium reprocessing plants [13], or following the use of depleted uranium (DU) in conflict zones [11, 14]. The persistent use of depleted uranium in weapon composition in the recent conflicts (Iraq in 1991 and 2001, Bosnia and Herzegovina in 1995, and Kosovo in 1999) 
continues to keep the scientific and social queries concerning the environmental contamination by such metal, as well as subsequent human exposure and possible consequences on health.

The particularity of uranium is its dual toxicity, due to its radiological effects as an alpha emitter and its chemical effects due to its properties as metal. However, the chemical toxicity of this radionuclide was considered as predominant in case of depleted and natural uranium. The major biological effects of uranium on health concern renal function $[15,16]$. According to these specific properties, most of guidelines concerning uranium levels were based on chemical effects of uranium on kidneys. As ingestion (by drinking water or alimentary chain) is the predominant way of human exposure for public in case of environmental exposure, guideline values concerning uranium level in drinking water were established by several national and international organizations. These guidelines were based on existing information about chemical effects of uranium, mainly in kidneys. Thus, the World Health Organization set a guideline value of $15 \mu \mathrm{g} / \mathrm{L}$ for uranium in drinking water [3], recently reevaluated at $30 \mu \mathrm{g} / \mathrm{L}$ [17]. This value, however, was provisional in view of several limitations pointed out by WHO [17] concerning the lack of extensive knowledge about the chronic effects of uranium in drinking water. These restrictions were in accordance with a recent review that claimed the need for more epidemiological and experimental studies [18]. Indeed, the existing epidemiological studies do not allow clearly demonstrating health effects of radionuclides at levels naturally encountered in drinking water due to methodological limitations (exposure assessment, possible confounders, and limited sample size). In addition, few experimental studies were performed with uranium levels close to real environmental situations. Considering the previous guideline of WHO [3], the value of $15 \mu \mathrm{g} / \mathrm{L}$ was derived from a single study of subchronic renal effects of uranium when administered to rats in drinking water for 3 months [19]. Moreover, several authors have since shown that the kidneys are not the only biological target of chronic exposure to low levels of uranium; for examples changes have been reported in the gastrointestinal system [20], in the central nervous system [21, 22], or in the liver [23].

These two points-the limitations of existing studies and necessity to take into consideration the recent concept that uranium affects multiple organs-led us to conduct new experimental studies of the results of chronic uranium exposure. The investigation of this present study focused on five organs/tissues: the small intestine, which is the entry route for uranium after ingestion [24]; the kidneys, traditionally considered the target organ of uranium following an acute contamination at high doses [16]; the hematopoietic cells that may be modified by uranium due to its accumulation in the bones and kidneys [25], and other organs described more recently as affected by chronic exposure at low levels: the liver [23] and the brain [22]. The objective was to evaluate the possible biological effects of uranium on the primary function of each organ/tissue. Concerning the intestines, we choose to investigate uranium effects on immune function of intestinal mucosa, because previous studies demonstrated a specific localization of uranium in immune cells of intestinal wall [26,
27]. The investigation of uranium effects on the kidneys and the liver was based on the different phases of the xenobiotic metabolism, since they are the major organs involved in detoxification processes of endo- and xenomolecules. In addition, cholesterol metabolism was studied in the liver, since this organ plays the central role in whole organism concerning this metabolism. The effects of uranium on the central nervous system were evaluated via two mechanisms, the uranium-induced oxidative stress and the cholinergic system. Indeed, a possible mechanism of uranium effects observed in cognitive functions may be due to the oxidative stress induced by reactive oxygen species imbalance.

In order to complete this investigation and to be sure to provide an extensive view of uranium effects in the present study, the analyses were performed at the several macroscopic and microscopic levels of organism (molecular, functional, structural, and pathological).

This study was performed in rats of a wide range of concentrations $(0.2,2,5,10,20,40$, or $120 \mathrm{mg} / \mathrm{L})$ of uranium in drinking water. These uranium levels include the uranium level of $0.2 \mathrm{mg} / \mathrm{L}$ close to values measured around mining areas [28], the uranium level of $1 \mathrm{mg} / \mathrm{L}$ close to the concentration of $0.96 \mathrm{mg} / \mathrm{L}$ that served to determine the previous WHO guideline of uranium level in drinking water [3], and the maximal concentration measured throughout the world (20 mg/L in Finland [29]). Duration of 9 months was chosen for the present study to mimic the chronic exposure of populations living on uranium-rich territories and to evaluate its long-term consequences.

\section{Material and Methods}

2.1. Animals. These experiments were conducted on 8-week old Sprague-Dawley male rats (Charles River, L'Arbresle, France) according to French regulations for animal experimentation (Ministry of Agriculture Act number 2001-464, 2001) and with the approval of IRSN animal welfare committee. Two rats were housed per cage at $21 \pm 2^{\circ} \mathrm{C}$ and a $12 \mathrm{~h}: 12 \mathrm{~h}$ cycle with free access to normal rat food (105, CERJ, France) and water. Animals were contaminated for 9 months with drinking water containing uranium (uranyl nitrate hexahydrate $\left(\mathrm{UO}_{2}\left(\mathrm{NO}_{3}\right)_{2} \cdot 6 \mathrm{H}_{2} \mathrm{O}\right)$ ) dissolved in mineral water for final concentration at $0.2,2,5,10,20,40$, or $120 \mathrm{mg} / \mathrm{L}$ (AREVA, France) (10 rats per group). The group of $40 \mathrm{mg} / \mathrm{L}$ was added in this study to serve as the reference group, as several studies have been published with this uranium level in drinking water $[20,23,30,31]$. Control animals drunk uncontaminated mineral water (which contains naturally uranium at $1.42 \mu \mathrm{g} / \mathrm{L}$ ). Alpha spectrometry following chemical separation was performed to determine uranium isotope ratio in the contaminated water according the standard norm $\mathrm{NF} M$ 60-805-5. The ${ }^{235} \mathrm{U} /{ }^{238} \mathrm{U}$ ratio of $0.25 \%$ indicated depleted uranium (Table 1), which was used in this study to address the chemical toxicity of this radionuclide. At the end of contamination, after overnight fasting, the animals were anesthetized by inhalation of 5\% isoflurane (Abbot France, Rungis, France) before being euthanized for tissue sampling. These experiments were conducted on male animals, since 
TABLE 1: Determination of uranium radioisotopes present in drinking water contaminated with $40 \mathrm{mg} / \mathrm{L}$.

\begin{tabular}{lcc}
\hline Uranium & & \\
${ }^{234} \mathrm{U}$ & $\mathrm{Bq} / \mathrm{L}$ & $93.4 \pm 6.5$ \\
${ }^{235} \mathrm{U}$ & $\mathrm{Bq} / \mathrm{L}$ & $8.70 \pm 1.13$ \\
${ }^{238} \mathrm{U}$ & $\mathrm{Bq} / \mathrm{L}$ & $531.5 \pm 31.9$ \\
\hline U total & $\mathrm{mg} / \mathrm{L}$ & $42.85 \pm 2.57$ \\
Ratio ${ }^{235} \mathrm{U} /{ }^{238} \mathrm{U}$ & $\%$ & 0.25 \\
\hline
\end{tabular}

Uranium was analysed by alpha spectrometry following chemical separation. See Material and Methods section for more details.

a previous study demonstrated that this gender in rats is more sensitive to uranium than the female is [19].

2.2. Uranium Measurements in Biological Samples. Biological samples were prepared by adding $8 \mathrm{~mL}$ nitric acid $70 \%$ ultrapure (INSTRA-analyzed for trace metal analysis, Sodipro, Echirolles, France) and $2 \mathrm{~mL}$ of hydrogen peroxide. They were then mineralized using a $1000 \mathrm{~W}$ microwave (Ethos Touch, Milestone Microwave Laboratory Systems, Sorisole, Italy). Before measurement, samples were diluted between $1 / 5$ and 1/500 depending on considered organ and administrated dose in $2 \%$ nitric acid. The samples were then analyzed for their uranium content by inductively coupled plasma mass spectrometry (ICP-MS) (XSERIE 2, Thermoelectron, France). Calibration was performed with a multielemental standard solution (Analab-STD-495, Analab, Bischheim, France). In all solutions likely to be analyzed (biological samples or calibration solutions), bismuth 209 was added as an internal standard. Further indications have been provided in a previous study [32]. For ${ }^{238} \mathrm{U}$, the detection and quantification limits were, respectively, $0.5 \mathrm{ng} / \mathrm{L}$ and $1.5 \mathrm{ng} / \mathrm{L}$, and for ${ }^{235} \mathrm{U}$, $0.01 \mathrm{ng} / \mathrm{L}$ and 0.03 . The limits for ${ }^{238} \mathrm{U}$ were applied to total uranium. Uranium was measured in kidney, bone (femur), liver, and brain (entorhinal cortex).

2.3. Biochemical Parameters in Blood. An automated spectrophotometric system (Konelab 20, Thermo Electron Corporation, Cergy-Pontoise, France) was used to measure these parameters, with biological chemistry reagents from the manufacturer or Diagam (Lille, France). Bilirubin was measured with the Thermo Electron Corporation kit. Kits from Diagam were used for measuring total cholesterol, low-density lipoprotein- (LDL-) cholesterol, highdensity lipoprotein- (HDL-) cholesterol, triglycerides, alanine aminotransferase (ALT), aspartate aminotransferase (AST), creatinine, urea, iron, ferritin, transferrin, and ceruloplasmin. Phospholipids B were measured with a kit provided by Diagnostic Partners (Bougival, France).

2.4. Blood Cell Counts. Blood was harvested by intracardiac puncture into either EDTA coated tubes for plasma isolation or dry tubes for serum isolation. Blood cell counts were performed by means of an MS-9 vet automatic counter (Melet-Schlossing, Osny, France). The remaining blood was centrifuged at $400 \mathrm{~g}$ for 10 minutes and plasma or serum was frozen for later use.

2.5. Cytokine Measurements. Flt-3 ligand concentration, a biological indicator of bone marrow function [33], and IL-7, a biological indicator of T lymphocyte homeostasis [34], were measured in plasma samples using ELISA kits according to manufacturer's recommendation (R\&D System, Abington, UK). Sensitivity was $7 \mathrm{pg} / \mathrm{mL}$ for Flt3-ligand ELISA test and $15 \mathrm{pg} / \mathrm{mL}$ for IL-7 ELISA test.

2.6. Colony-Forming Cell Assay. Femurs were flushed with $5 \mathrm{~mL}$ washing medium (MEM- $\alpha$ medium supplemented with $1 \%$ fetal calf serum (FCS) and antibiotics, both from Life Technologies, Cergy-Pontoise, France). Spleen cells were crushed in Tenbrock's Potter in the presence of $5 \mathrm{~mL}$ washing medium. After washing twice ( $8 \mathrm{~min}$ at $400 \mathrm{~g}$ ), cells were numbered and viability assessed in the presence of Trypan Blue. Cells were then plated at $5 \times 10^{5}$ for spleen cells and $5 \times 10^{4}$ bone marrow cells in $1.1 \mathrm{~mL}$ of complete methylcellulose medium with cytokines (Stem Cell Technologies, Vancouver, Canada). Cultures were incubated at $37^{\circ} \mathrm{C}$ in $95 \%$ air $/ 5 \% \mathrm{CO}_{2}$ in a humidified atmosphere. Colony-forming units-granulocyte macrophage (CFU-GM) and burst-forming units-erythroid (BFU-E) were scored on day 12 of culture.

2.7. Histology and Immunohistochemistry. After fixation in 4\% formaldehyde solution (Carlo Erba, Rueil Malmaison, France), tissues were dehydrated, embedded in paraffin, and cut in sections $5 \mu \mathrm{m}$ thick. Hematoxylin-eosin-saffron staining was then performed in sections of liver, kidney, and terminal ileum by an independent laboratory (Biodoxis, Romainville, France).

Determination of immune cells was also performed in terminal ileum by immunohistochemistry or histochemistry as previously reported in [20]. The tissue neutrophil infiltration was estimated on paraffin sections incubated with rabbit antibody directed against rat myeloperoxidase (IMG antibody, $d=1 / x 00$, Clinisciences, Nanterre, France) and LSAB2 HRP kit (Dako, Trappes, France). The macrophages were visualized with mouse antibody against CD68 (Serotec, Cergy Saint Christophe, France) followed by histofine simple stain mouse MAX PO (Microm Microtech, Francheville, France). For mast cell coloration, the ileal segments were fixed in Carney solution. Histological slides were then stained with Alcan Blue method. Neutrophils and mast cells were quantified by determining the number of their respective cells per crypt-villus axis. The results were expressed as mean $\pm \mathrm{SD}$ of 8 animals. A qualitative analysis was realized for macrophages with establishment of a scoring of macrophage density network in crypts and villi.

2.8. Gene Expression. The different genes measured in the different organs were indicated in the Table 2. Total RNA was prepared from tissues $(\sim 30 \mathrm{mg}$ for liver, kidney, entorhinal cortex, and ileum) with the RNeasy Mini Kit (Qiagen, 
TABLE 2: Primer sequences for rat genes studied in several organs following chronic ingestion of uranium.

\begin{tabular}{|c|c|c|}
\hline Genes & Forward & Reverse \\
\hline HPRT & $5^{\prime}$-GCTCGAGATGTCATGAAGGAGA-3' & $5^{\prime}$-TCAGCGCTTTAATGTAATCCAGC-3' \\
\hline & \multicolumn{2}{|c|}{ Cytokines } \\
\hline CCL-2 & $5^{\prime}$-CAGCCAGATGCAGTTAATGCC-3' & $5^{\prime}$-AGCCGACTCATTGGGATCAT-3' \\
\hline $\mathrm{TNF} \alpha$ & $5^{\prime}$-ATCCGAGATGTGGAACTGGC-3' & $5^{\prime}$-CGATCACCCCGAAGTTCAGTA-3' \\
\hline $\operatorname{IFN} \gamma$ & $5^{\prime}$-CACGCCGCGTCTTGGT-3' & $5^{\prime}$-TCTAGGCTTTCAATGAGTGTGCC-3' \\
\hline TGF $\beta$ & $5^{\prime}$-TCCCAAACGTCGAGGTGAC-3' & $5^{\prime}$-CAGGTGTTGAGCCCTTTCCA-3' \\
\hline \multirow[t]{2}{*}{ IL-10 } & $5^{\prime}$-GTTGCCAAGCCTTGTCAGAAA-3' & $5^{\prime}$-TTTCTGGCCATGGTTCTCT- $3^{\prime}$ \\
\hline & \multicolumn{2}{|c|}{ Xenobiotic metabolising enzymes } \\
\hline CYP3A2 & 5'-AGTAGTGACGATTCCAACATAT-3' & $5^{\prime}$-TCAGAGGTATCTGTGTTTCCT-3' \\
\hline CYP2C11 & $5^{\prime}$-ATGGGATGCAATGGAAGGAG-3' & $5^{\prime}$-TCTTGCCCATCCCAAAAGTC-3' \\
\hline ST1A1 & $5^{\prime}$-AGGGTGGCAAGCTAGAGAAGTG-3' & 5'-GAGGGAACCCCTGGACATTT-3' \\
\hline GSTA2 & $5^{\prime}$-TTGACATGTATTCAGAGGGT-3' & $5^{\prime}$-TTGTTTTGCATCCATGGCTG-3' \\
\hline UGT1A1 & $5^{\prime}$-TGGCATCCCCAAAACGATCT-3' & $5^{\prime}$-GGAACCGGAGTGTGTGATGAA-3' \\
\hline UGT2B1 & $5^{\prime}$-TGGAGAACATGGTGTAGTGGT-3' & $5^{\prime}$-TTGGCTTTTTCTTCAGTAGTCAGG-3' \\
\hline MDR1 & $5^{\prime}$-ATCAACTCGCAAAAGCATCC-3' & $5^{\prime}$-AATTCAACTTCAGGATCCGC-3' \\
\hline \multirow[t]{2}{*}{ MRP2 } & 5'-TTCGAAGCTGGATGATGTGTTT-3' & $5^{\prime}$-GCCATGCAGATCATGACAAGAG-3' \\
\hline & \multicolumn{2}{|c|}{ Enzymes of cholesterol metabolism } \\
\hline HMGR & $5^{\prime}$-GGCGGGTCCTGCAAGTG-3' & $5^{\prime}$-GCAGGTGAGCGGGTGAGA-3' \\
\hline CYP27A1 & $5^{\prime}$-GGAAGGTGCCCCAGAACAA- $3^{\prime}$ & $5^{\prime}$-GCGCAGGGTCTCCTTAATCA-3' \\
\hline CYP7A1 & $5^{\prime}$-CCAAGTCAAGTGTCCСССТСТA-3' & $5^{\prime}$-GACTCTCAGCCGCCAAGTG-3' \\
\hline CYP8B1 & $5^{\prime}$-GTACACATGGACCCCGACATC- $3^{\prime}$ & $5^{\prime}$-GGGTGCCATCAGGGTTGAG-3' \\
\hline CYP7B1 & $5^{\prime}$-TCAGATGCAAAGACGGTCAGA-3' & 5'-TTCATGCCCGTAGTATTTTTTCAG-3' \\
\hline ACAT2 & $5^{\prime}$-GCCCCAGCCGACATTTT-3' & $5^{\prime}$-GTGCAGTGTGAAGCCTTGACTT-3' \\
\hline ABCA1 & $5^{\prime}$-ATCTCATAGTATGGAAGAATGTGAAGCT-3' & $5^{\prime}$-CGTACAACTATTGTATAACCATCTCCAAA-3' \\
\hline ABCG5 & $5^{\prime}$-CGCAGGAACCGCATTGTAA- $3^{\prime}$ & $5^{\prime}$-TGTCGAAGTGGTGGAAGAGCT-3' \\
\hline LDL-r & $5^{\prime}$-CAGCCGATGCATTCCTGACT-3' & 5'-AGTTCATCCGAGCCATTTTCAC-3' \\
\hline SR-B1 & $5^{\prime}$-GTTGGTCACCATGGGCCA-3' & $5^{\prime}$-CGTAGCCCCACAGGATCTCA-3' \\
\hline ApoA1 & $5^{\prime}$-AATGGGACAGGGTGAAGGA-3' & $5^{\prime}$-TGAACCCAGAGTGTCCCAGTT-3' \\
\hline ApoB & $5^{\prime}$-TCCTAACATCATTGTGCCTTCAT-3' & $5^{\prime}$-CCTTGAAATCTGGGAGGGAAAACT-3' \\
\hline LXR $\alpha$ & $5^{\prime}$-AGCAACAGTGTAACAGGCGCT-3' & $5^{\prime}$-GTGCAATGGGCCAAGGC-3' \\
\hline FXR & $5^{\prime}$-TGACAAAGAAGCCGCGAAT- $3^{\prime}$ & 5'-TGTAATGGTACCCAGAGGCCC-3' \\
\hline $\mathrm{RXR} \alpha$ & $5^{\prime}$-CGCAAAGACCTGACCTACACC-3' & $5^{\prime}$-TCCTCCTGCACGGCTTCCC-3' \\
\hline SREBP2 & $5^{\prime}$-AGCTGGCAAATCAGAAAAACAAG-3' & $5^{\prime}$-CGATCTTCAAGTCCACATCACTGT-3' \\
\hline $\operatorname{PPAR} \alpha$ & $5^{\prime}$-ТСТСТТСССААААСТССТТСА- $3^{\prime}$ & $5^{\prime}$-GCACGAGCTGCGCATGCTC-3' \\
\hline $\operatorname{PPAR} \gamma$ & $5^{\prime}$-TCA TGA CCA GGG AGT TCC TCA-3' & $5^{\prime}$-TCATCTAATTCCAGTGCATTGAACTT-3' \\
\hline
\end{tabular}

Courtaboeuf, France) following the manufacturer's instructions. The NanoDrop apparatus (ThermoFisher Scientific, Cergy Pontoise, France) was used for determining the concentration of RNA in $n g / \mu \mathrm{L}$. For the reverse transcription, $1 \mu \mathrm{g}$ of total RNA was reverse transcribed at $37^{\circ} \mathrm{C}$ for $120 \mathrm{~min}-$ utes using the High Capacity cDNA Reverse Transcription kit (Applied Biosystems, Courtaboeuf, France) according to the manufacturer's instructions. Real-time semiquantitative analysis was performed with the Abi PRISM 7900 sequence detection system (Applied Biosystems). The PCR amplification was performed using Syber PCR master mix (Qiagen) in a final volume of $25 \mu \mathrm{L}$. Sequences for the forward and reverse primers of different genes studied in the present study are listed in Table 2 . The relative mRNA quantification of the target gene was made by using the comparative $\Delta \Delta \mathrm{CT}$-method
[35]. Data were first normalized to an endogenous reference (HPRT: hypoxanthine-guanine phophoribosyltransferase, a housekeeping gene) and expressed as the level relative to the uncontaminated controls (mean $\pm \mathrm{SD} ; n=10$ ).

2.9. Determination of Inflammatory Mediators in Intestine. Mucosal samples were obtained by scraping the rat terminal ileum at euthanasia and were kept at $80^{\circ} \mathrm{C}$ until analysis. Mucosal protein extracts were obtained from tissue homogenates performed using ribolyser (FastPrep 120, ThermoSavant, ThermoScientific, Cergy Pontoise, France) in phosphate buffer ( $\mathrm{pH}=7.4$, PBS, Gibco, Invitrogen, Cergy Pontoise, France) containing a protease inhibitor cocktail (0.5 mL/100 mL, Sigma, L'Isle D’Abeau Chesnes, France). 
This step was followed by a centrifugation step (10000 g, 10 minutes). Tissue levels of cytokines were measured by ELISA assays: TNF $\alpha, \operatorname{IFN} \gamma$, and IL-10 were measured using Duoset kit ELISA (R\&D systems, Lille, France) and CCL-2 using the Kit rat MCP-1 (Clinisciences, Montrouge, France). To ensure a higher sensitivity and a much greater dynamic range than that of classical colorimetric revelation by tetramethylbenzidine (TMB) substrate, a chemiluminescent substrate (luminol/peroxide substrate) is added to the wells (Glo Substrate, R\&D systems, Lille, France). The results were expressed per mg of protein determined with Bradford assay (Sigma, L'Isle D’Abeau Chesnes, France).

2.10. Expression of Enzymes of Xenobiotics Metabolism Measured by Western Blotting on Liver and Kidney Samples. Proteins from tissue homogenates (microsome or cytosol) were prepared as described in [23]. These proteins were loaded, separated by $10 \%$ SDS-polyacrylamide gel electrophoresis and transferred onto nitrocellulose membrane. The membranes were blocked for $1 \mathrm{~h}$ in $5 \%$ nonfat dry milk in TBS. The blots were incubated overnight with antibodies diluted in $2 \%$ nonfat dry milk in TBS at $4^{\circ} \mathrm{C}$. Microsomal CYP3A1 and CYP3A2 were detected using rabbit polyclonal antibodies (Abcam, Paris, France). Microsomal CYP2C11 was detected using goat polyclonal antibodies (Daiichi Pure Chemicals, Tokyo, Japan). Measurements of microsomal (CYP3A1, CYP3A2, CYP2C11, and UGT2B1) and cytosolic (GST2a) enzymes were detected and measured as described [36]. Microsomal UGT2B1 was detected using goat polyclonal antibodies and rabbit polyclonal antibodies, respectively (Santa Cruz Biotechnology, Heidelberg, Germany). Cytosolic GST2a was detected using goat antibody (Oxford Biomedical Research, Oxford, USA). Immune complexes were revealed by rabbit anti-goat IgG and goat anti-rabbit IgG (Santa Cruz Biotechnology) coupled to horseradish peroxidase (HRP) and the luminol derivative of Immobilon Western (Millipore, Billerica, USA). Samples were normalized to glyceraldehyde 3-phosphate dehydrogenase (GAPDH) which was detected using rabbit anti-rat antibody (Santa Cruz Biotechnology). Reaction intensity was determined by computer-assisted densitometry (Fuji Las3000, Raytest, France). Samples were normalized to glyceraldehyde 3-phosphate dehydrogenase (GAPDH).

2.11. Xenobiotic Metabolism Enzyme Activity in the Liver. Freshly prepared microsomal fractions were used to measure testosterone hydroxylase activity [36]. The enzymatic activity of $2 \alpha$-testosterone hydroxylase (CYP2C11) and $6 \beta$ testosterone hydroxylase (CYP3A1/2) was expressed as picomoles per minute per whole liver and normalized to that of the noncontaminated group.

2.12. Cholesterol Metabolism Enzyme Activity in the Liver. The specific activities of cytochromes P450 CYP27A1 and CYP7A1 were assessed, respectively, on hepatic mitochondrial and microsomal fractions, with a radioisotopic method [37]. Enzymatic activity was expressed as picomoles per minute per milligram. The results are expressed as mean \pm SEM of 6 animals.

2.13. Antioxidant Status in the Brain. The tissues were prepared as described in [30]. Each cerebral sample was measured in duplicate. The tissues were homogenized in ice-cold 0.1 M phosphate-buffered saline (PBS, pH 7.4) containing $1 \mathrm{mM}$ EDTA. The homogenates were centrifuged at $10000 \mathrm{~g}$ for $15 \mathrm{~min}$ at $4^{\circ} \mathrm{C}$, and the supernatants were collected for analyses. Protein concentrations were determined by Bradford method using bovine serum albumin as a standard. The activity of CAT (catalase), SOD (superoxide dismutase), glutathione peroxidase (GPx), and total glutathione (GSH) was determined with commercial kits (Bertin Pharma, Montigny-le-Bretonneux, France).

For CAT activity, the method is based on the reaction of the enzyme with methanol in the presence of an optimal concentration of $\mathrm{H}_{2} \mathrm{O}_{2}$. The formaldehyde produced is measured spectrophotometrically with 4-amino-3-hydrazino-5mercapto-1,2,4-triazole (Purpald) as the chromogen. The CAT activity was expressed in nmol of formaldehyde per min per mg protein.

SOD activity is assessed by using a tetrazolium salt for detection of superoxide radicals generated by xanthine oxidase and hypoxanthine. The SOD assay measures all three types of SOD (Cu/Zn-, Mn-, and Fe-SOD). One unit of SOD is defined as the amount of enzyme needed to exhibit $50 \%$ dismutation of the superoxide radical. The enzyme units were recorded as $\mathrm{U}$ per $\mathrm{mg}$ protein.

GPx activity was indirectly measured by a coupled reaction with glutathione reductase (GR). Oxidized glutathione (GSSH), produced upon reduction of hydroperoxyde by GPx, is recycled to its reduced state by GR and NADPH. The oxidation of NADPH to $\mathrm{NADP}^{+}$is accompanied by a decrease in absorbance at $340 \mathrm{~nm}$, which is directly proportional to the GPx activity. The enzyme units were recorded as nmol NADPH oxidized per min per mg protein.

Cayman's GSH assay kit utilizes a carefully optimized enzymatic recycling method, using glutathione reductase for the quantification of GSH. The rate of TNB (5-thio-2nitrobenzoic acid), produced by the reaction of the sulfhydryl group of GSH with DTNB, is directly proportional to the recycling reaction which in turn is directly proportional to the concentration of GSH. Measurement of the absorbance of TNB at $405 \mathrm{~nm}$ provides thus an accurate estimation of GSH. GSH is easily oxidized to the disulfide dimer GSSG. Both GSH and GSSG are measured in this assay kit and the assay reflects thus total glutathione.

2.14. Cholinergic Pathway in the Cerebral Cortex. Acetylcholine rates and acetylcholinesterase activity were measured in the entorhinal cortex with the Amplex Red Acetylcholine/Acetylcholinesterase Assay Kit (Molecular Probes, Invitrogen, Cergy Pontoise, France) as described in [38]. For both assays, samples of $\sim 30 \mathrm{mg}$ were diluted in Tris- $\mathrm{HCl}$ buffer (final volume of $100 \mu \mathrm{L}$ ). A $100 \mu \mathrm{L}$ volume of $400 \mu \mathrm{M}$ Amplex Red Reagent containing $2 \mathrm{U} / \mathrm{mL}$ of $\mathrm{HRP}, 0.2 \mathrm{U} / \mathrm{mL}$ of choline oxidase, and $1 \mathrm{U} / \mathrm{mL}$ acetylcholinesterase was 


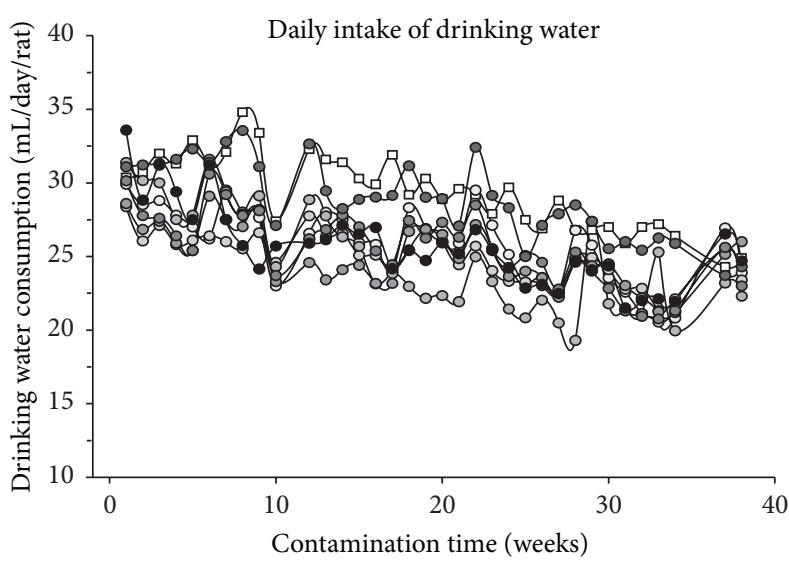

(a)

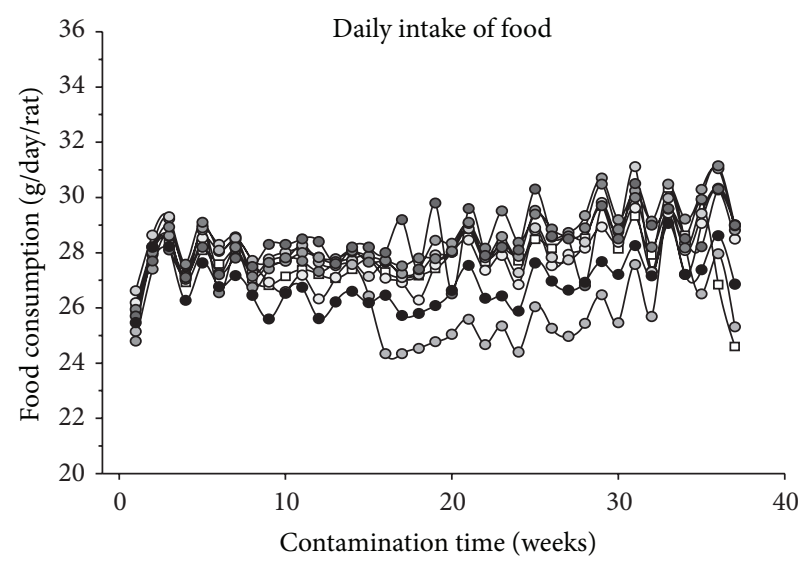

(b)

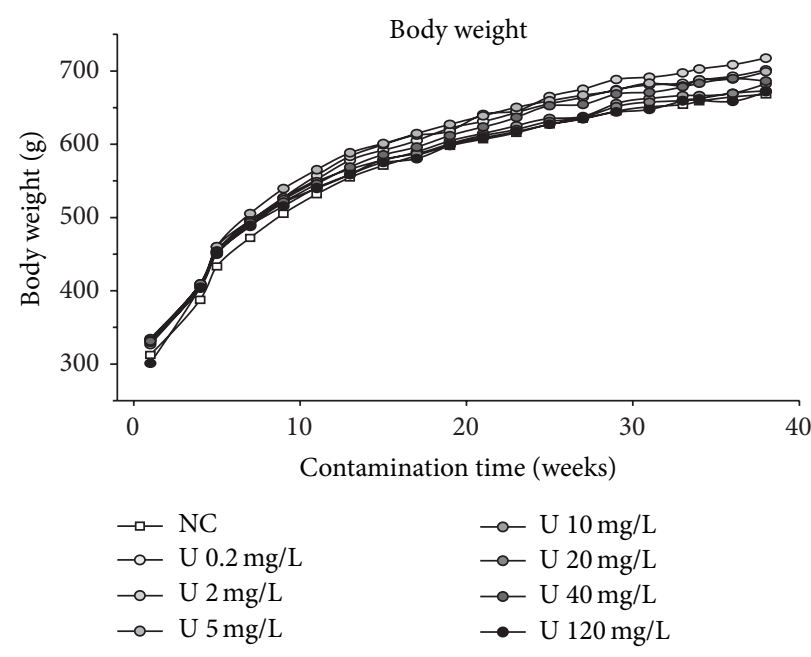

(c)

FIGURE 1: Effect of chronic ingestion of uranium on body weight, food, and drinking water intakes. Three parameters were recorded weekly in control group (open square) and in animals contaminated with uranium at $0.2,2,5,10,20,40$, or $120 \mathrm{mg} / \mathrm{L}$ (close circles). For standardization, drinking water consumption was expressed as $\mathrm{mL}$ per day per rat, food consumption was expressed as g per day per rat, and body weight was expressed by $g$. The indicated values are mean of $n=10$ animals for body weight and $n=5$ for daily intake of food and drinking water (two rats were housed per cage). For a clearer visualization, the SD of these values were not indicated in this figure: they were below $30 \%$ of mean values. There are no significant differences between control and contaminated groups.

added to samples. Results were expressed as $\mu \mathrm{M} / \mu \mathrm{g}$ protein. Absorbance was measured at $595 \mathrm{~nm}$ following a $45 \mathrm{~min}$ incubation at room temperature. The acetylcholinesterase assay was performed with a working solution of $200 \mu \mathrm{M}$ Amplex Red Reagent containing $2 \mathrm{U} / \mathrm{mL}$ of HRP, $0.2 \mathrm{U} / \mathrm{mL}$ of choline oxidase, and $100 \mu \mathrm{M}$ of acetylcholine. Absorbance was measured at $595 \mathrm{~nm}$ after 30 minutes of incubation at room temperature. Results were expressed as $\mu \mathrm{mole} / \mathrm{mg}$ protein/hour.

2.15. Statistical Analysis. Results are presented as mean \pm $\mathrm{SD}$ from 5 to 10 animals, depending on the parameters measured. The control and each of the contaminated groups were compared with one-way ANOVA analysis and the post hoc Holm-Sidak method. Statistical significance was defined by a $P$ value $\leq 0.05$. All statistical analyses were performed with SigmaStat, Statistical Software (SPSS, Paris, France).

\section{Results}

3.1. Health Parameters: Body Weight Gain, Food Intake, and Water Consumption. Body weight as well as food and drinking water intakes following 9-month chronic ingestion of uranyl nitrate was given in Figure 1. For a better visualization of the different curves, only means were indicated in this figure. The mean \pm SD of the control group (noncontaminated) was $24.7 \pm 6.0$ for drinking water intake (mL/day), $26.9 \pm$ 2.7 for food intake (g/day), and $672 \pm 73$ for body weight (g), at the end of experiment (9-month contamination). The results show that these chronic contaminations did not affect general health parameters, whatever the uranium content in drinking water (from 0.2 to $120 \mathrm{mg} / \mathrm{L}$ ) (one-way analysis ANOVA, NS), indicating that these different uranium levels were not toxic for animals following a chronic exposure. In addition, these values allow the calculation of daily intake of 


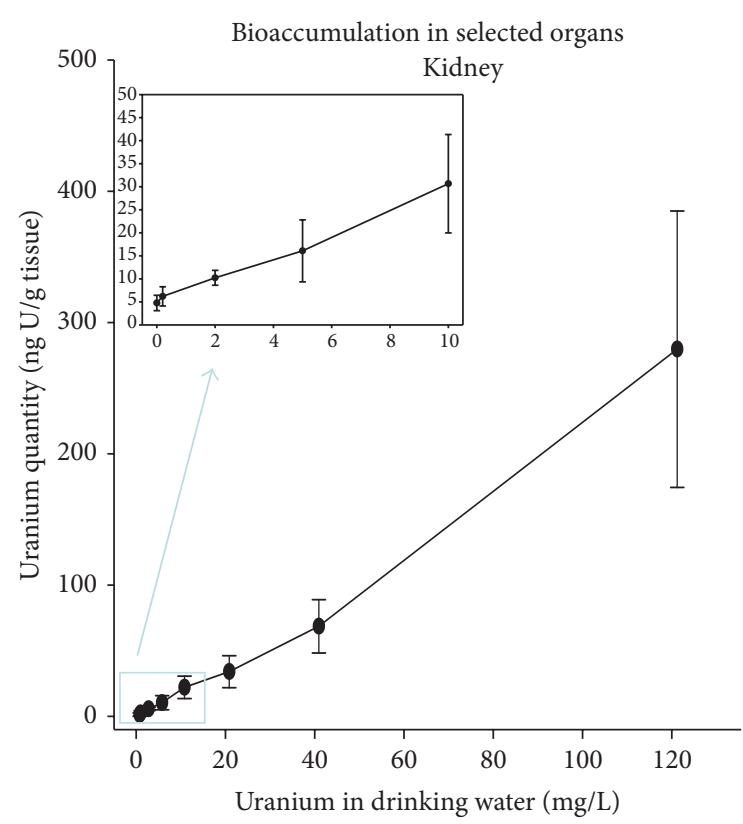

(a)

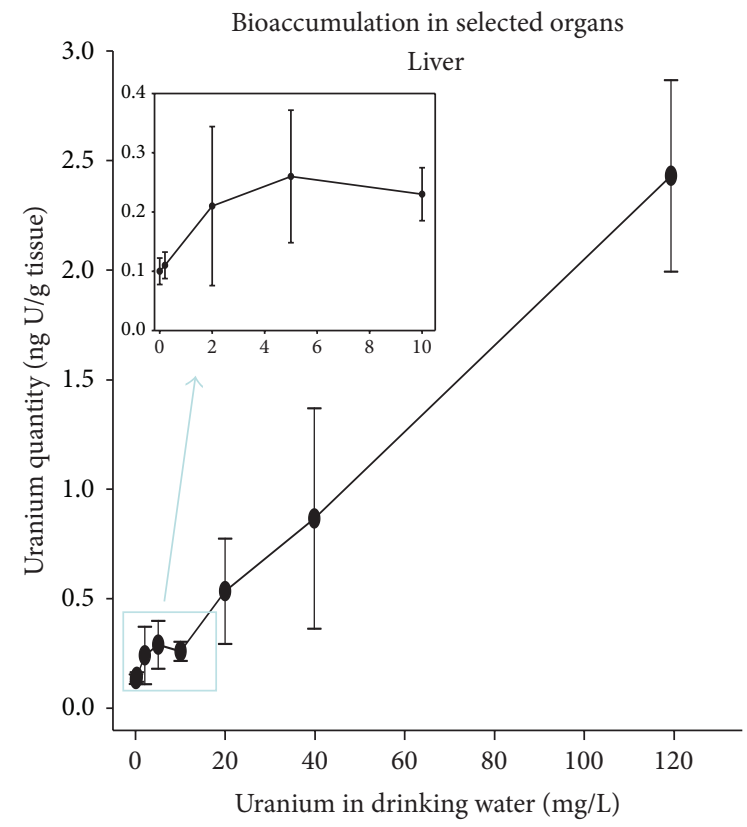

(c)

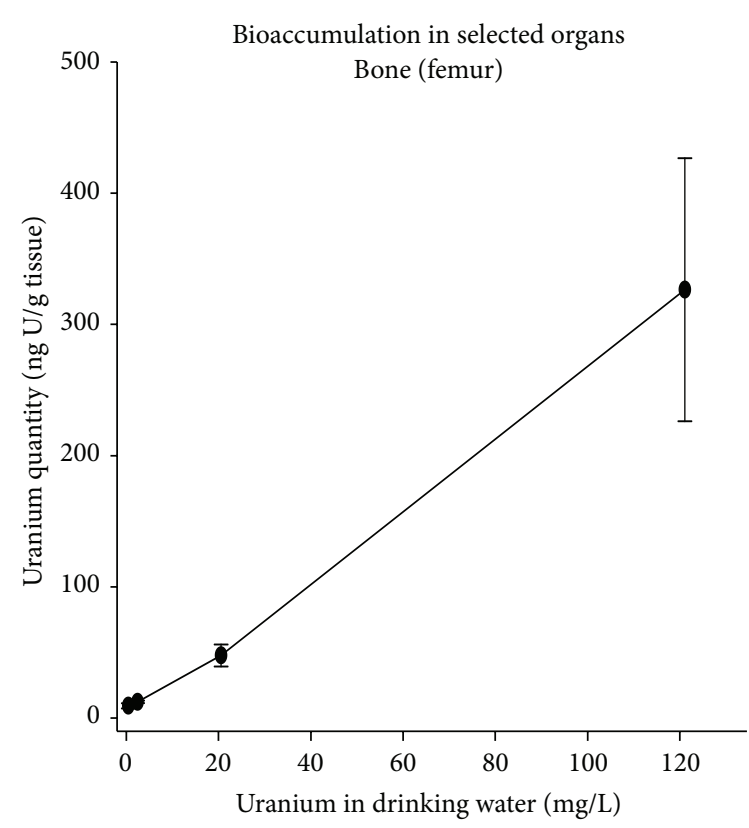

(b)

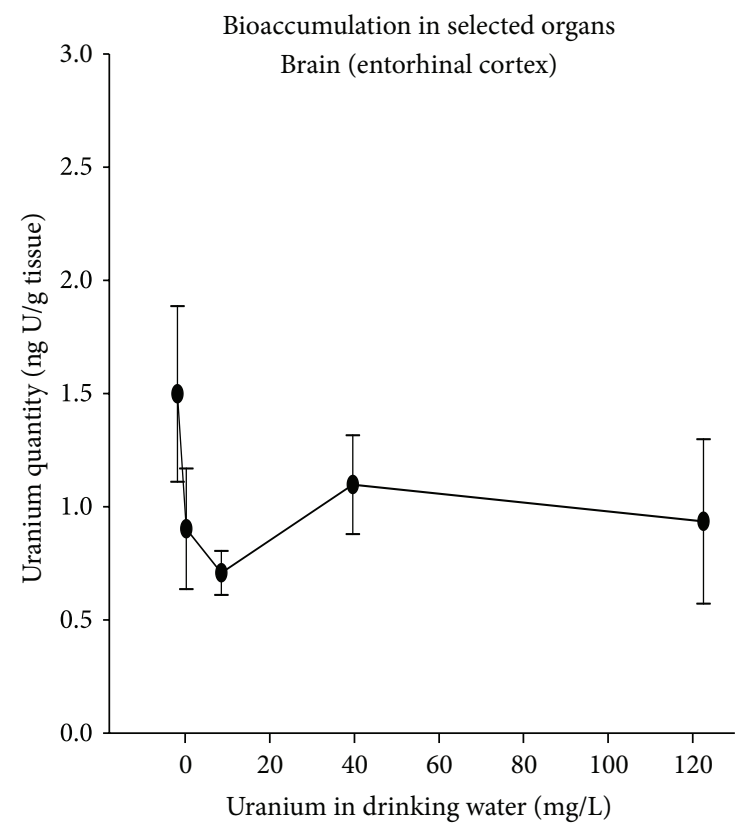

(d)

FIGURE 2: Bioaccumulation of uranium in organs after chronic ingestion for 9 months. Uranium was measured in organs (the kidney, femur, liver, and brain (entorhinal cortex)) by ICP-MS (see Material and Methods section for details). The results are expressed as ng/g tissue for 10 animals in the kidney and femur and for 4-6 in the liver and entorhinal cortex. The insets in the figures on the left (kidney and liver) show the increase in uranium accumulation for the lowest U levels (from 0.2 to $10 \mathrm{mg} / \mathrm{L}$ ).

uranium throughout the experiment. Dependent on age and body weight, the daily intake of uranium was estimated to be between 10.8 at the beginning of experiment and $3.6 \mathrm{mg} / \mathrm{kg}$ body weight per day 9 months later (mean: $5.4 \mathrm{mg} / \mathrm{kg} / \mathrm{d}$ ) for the highest level $(120 \mathrm{mg} / \mathrm{L})$. The mean daily intake of uranium was estimated to be $0.009,0.09,0.23,0.45,0.9$, 1.8 , and $5.4 \mathrm{mg} / \mathrm{kg} / \mathrm{d}$ for $0.2,2,5,10,20,40$, and $120 \mathrm{mg} / \mathrm{L}$, respectively.
Furthermore, no changes in macroscopic appearance or weights of organs (kidney, liver, and spleen) were noted following chronic ingestion by uranium (data not shown).

3.2. Uranium Accumulation in Organs. Uranium accumulation was measured in different organs after 9-month chronic contamination by ingestion. These measurements 


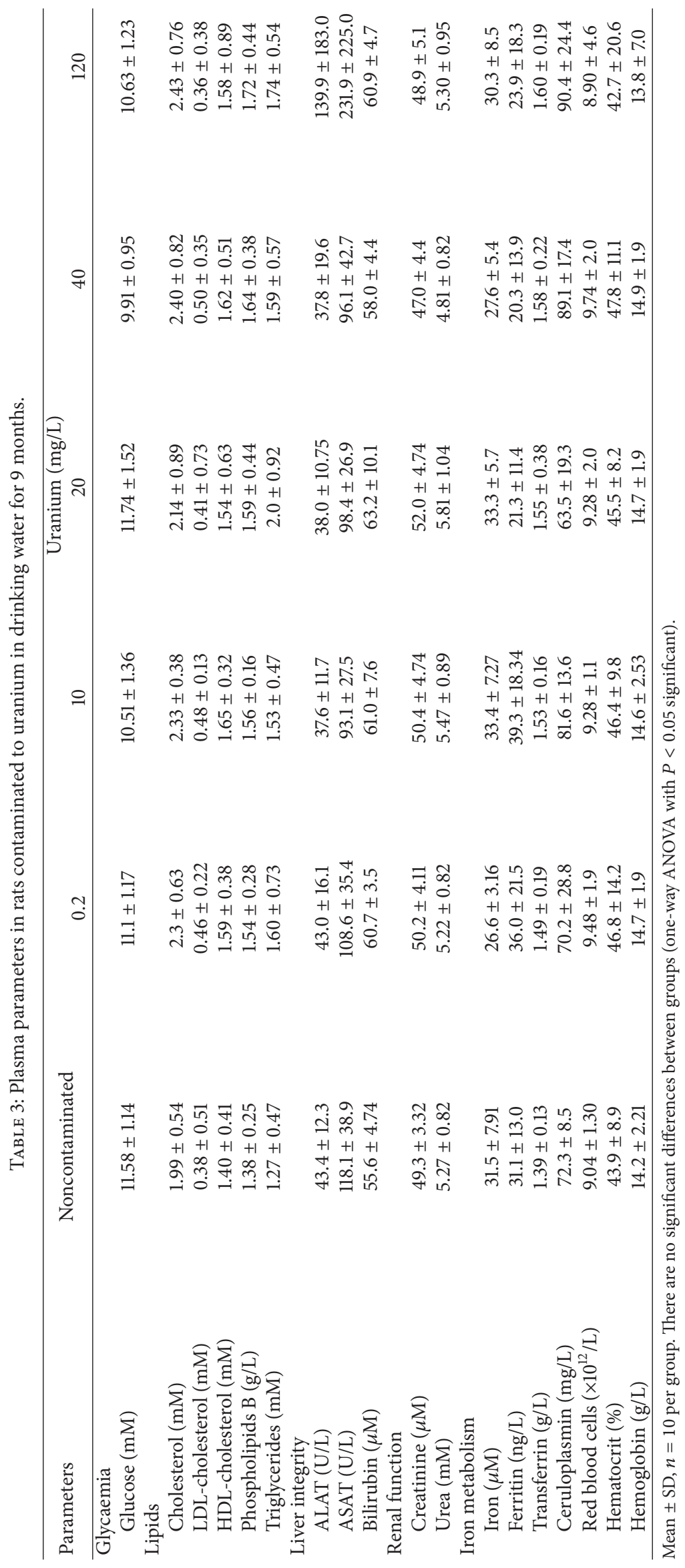




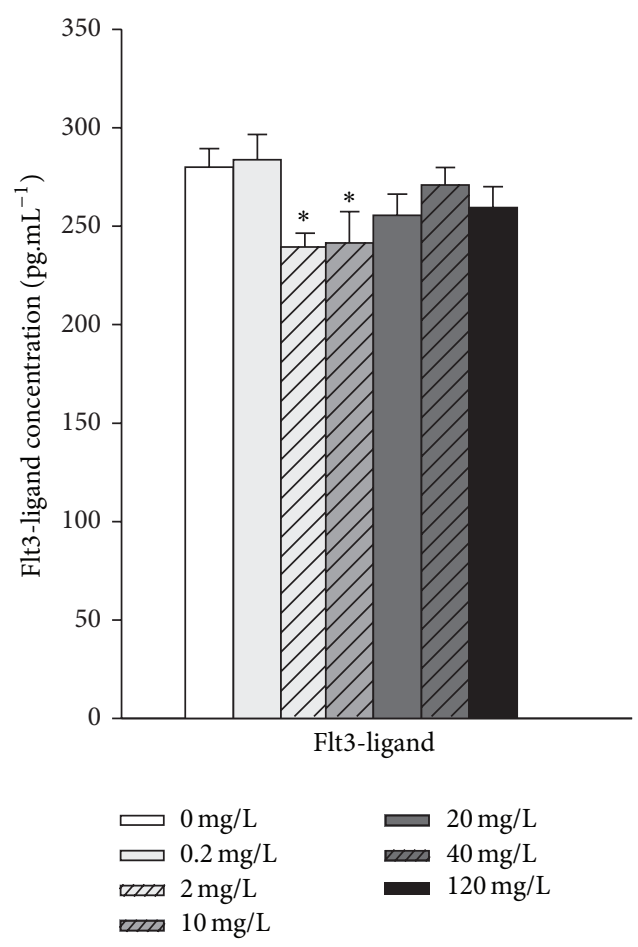

(a)

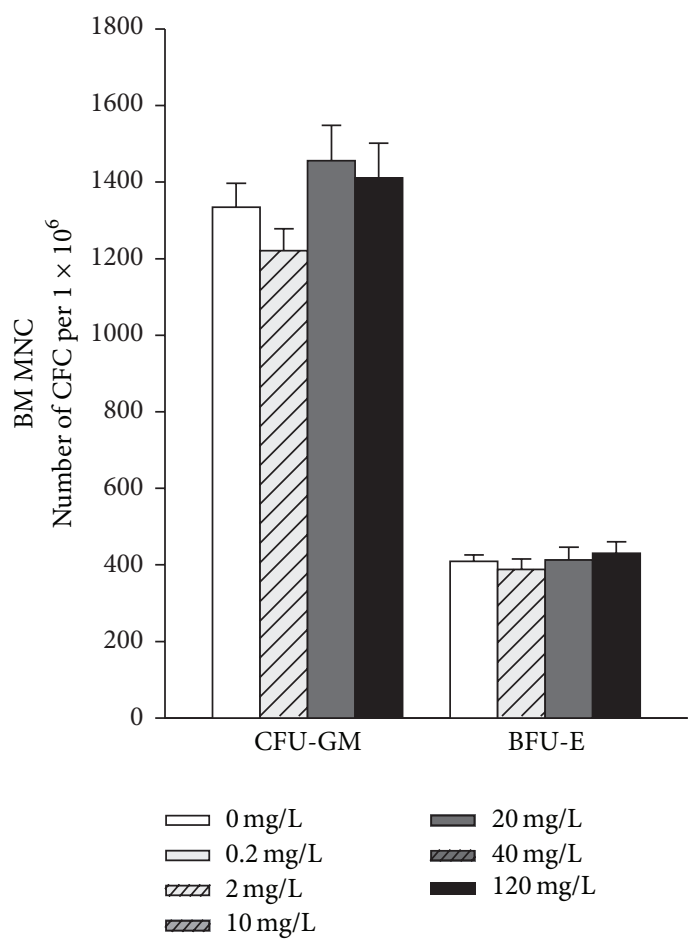

(b)

Figure 3: (a) Flt3-ligand in the plasma of animals contaminated through uranium ingestion. A significant difference was observed between 2 and $10 \mathrm{mg} / \mathrm{L}$ contaminated animals and control animals $(P<0.05, n=10)$. (b) Progenitor frequency in the bone marrow of control and contaminated animals. Results did not show any significant difference between control and contaminated animals $(n=5$ animals per group) both for burst forming units erythroid (BFU-E) and colony-forming units-granulocyte macrophages (CFU-GM).

were performed in selected organs, that is, the two storage organs of uranium, that is, kidney and bone (femur), as well as liver and brain (entorhinal cortex). Results are indicated in Figure 2. These results show an increasing accumulation of uranium in kidney and bone, depending on the ingested uranium level. These accumulations appeared to be similar in both organs at $120 \mathrm{mg} / \mathrm{L}$. In kidney, the ingestion of the highest level of contamination $(120 \mathrm{mg} / \mathrm{L})$ led to a uranium concentration of $352 \mathrm{ng} \mathrm{U} / \mathrm{g}$ tissue. Concerning the other organs, liver and brain, uranium accumulation was very low as compared to kidney, since the uranium quantity in these tissues was 100 -fold less. Uranium quantity in liver is $2.45 \pm 0.45 \mathrm{ng} / \mathrm{g}$ at $120 \mathrm{mg} / \mathrm{L}, 0.85 \pm 0.51 \mathrm{ng} / \mathrm{g}$ at $40 \mathrm{mg} / \mathrm{L}$, and $0.10 \pm 0.02$ in noncontaminated animals. The uranium accumulation at $120 \mathrm{mg} / \mathrm{L}$ corresponds to 2 orders of magnitude less than in the kidneys. The inset linked to the graph representative of uranium accumulation in liver indicates that concentration of $20 \mathrm{mg} / \mathrm{L}$ of uranium in drinking water corresponds to a threshold level for uranium accumulation in liver. In central nervous system, the quantities of uranium measured in central nervous system remained extremely low, even at the highest level of $120 \mathrm{mg} / \mathrm{L}$. In fact, there is no dosedependent accumulation of uranium in brain $(0.98 \pm 0.34$ at $120 \mathrm{mg} / \mathrm{L}$ versus $1.5 \pm 0.36 \mathrm{ng} / \mathrm{g}$ in control group).

3.3. Plasma Biochemical Parameters. Plasma biochemical parameters are shown in Table 3. In this table are reported various plasma parameters concerning lipid profile, liver integrity, renal function, and iron metabolism. The results show no changes following a chronic ingestion of uranium for any of these measures (one-way ANOVA analysis, NS). The absence of any difference in plasma concentrations of kidney function markers (creatinine and urea), even at the highest uranium level $(120 \mathrm{mg} / \mathrm{L})$, indicates that there was no nephrotoxicity after 9 months of chronic contamination. An increase in the ALAT ( 3 folds) and ASAT ( 2 folds) plasma concentrations reflecting liver integrity was noted in the highest group as compared with control group. However, this difference in liver function was not significant, mainly because of great variability in the $120 \mathrm{mg} / \mathrm{L}$ group.

3.4. Evaluation of Haematopoiesis. Blood cell counts were performed with differential for granulocytes, lymphocytes, monocytes, platelets, and red blood cells (RBC) (Tables 3 and 4). No significant differences were detected in circulating white blood cells, lymphocytes, granulocytes, or monocytes, regardless of the uranium exposure level. As well, there is no significant difference in RBC numbers, nor in haemoglobin concentration and in haematocrit (Table 3). Two cytokines were also measured in plasma samples, namely, Flt3-ligand and IL-7. The blood level of IL-7 did not vary significantly at any exposure level (data not shown). This indicates that uranium ingestion did not modify T lymphocyte homeostasis at the levels of uranium concentration studied. By contrast, the concentration of the Flt3-ligand was significantly lower in the plasma of animals ingesting 2 and $10 \mathrm{mg} / \mathrm{L}$ (Figure 3(a)). 
TABLE 4: Blood cell counts and differential in rats ingesting uranium through drinking water during 9 months.

\begin{tabular}{|c|c|c|c|c|c|c|}
\hline \multirow{2}{*}{$\begin{array}{l}\text { Cell lineage }\left(\times 10^{9} \text { per } L \text { of }\right. \\
\text { blood })\end{array}$} & \multirow{2}{*}{ Noncontaminated } & \multicolumn{5}{|c|}{ Uranium $(\mathrm{mg} / \mathrm{L})$} \\
\hline & & 0.2 & 10 & 20 & 40 & 120 \\
\hline White blood cells & $4.43 \pm 1.58$ & $6.19 \pm 1.01$ & $5.83 \pm 2.72$ & $5.40 \pm 1.83$ & $5.31 \pm 1.64$ & $6.20 \pm 4.11$ \\
\hline Lymphocytes & $3.22 \pm 1.23$ & $3.20 \pm 1.39$ & $7.45 \pm 1.33$ & $5.85 \pm 1.11$ & $4.06 \pm 1.33$ & $3.70 \pm 1.83$ \\
\hline Granulocytes & $1.07 \pm 0.54$ & $1.67 \pm 0.35$ & $1.52 \pm 0.70$ & $1.32 \pm 0.28$ & $1.15 \pm 0.41$ & $2.35 \pm 2.43$ \\
\hline Monocytes & $0.08 \pm 0.03$ & $0.13 \pm 0.03$ & $0.12 \pm 0.06$ & $0.10 \pm 0.03$ & $0.10 \pm 0.03$ & $0.15 \pm 0.13$ \\
\hline Platelets & $472 \pm 484$ & $603 \pm 847$ & $229 \pm 351$ & $177 \pm 395$ & $455 \pm 496$ & $165 \pm 405$ \\
\hline
\end{tabular}

Mean SD, $n=9-10$ per group. There are no significant differences between groups (one-way ANOVA with $P<0.05$ significant).

This suggested that uranium ingestion induced an increase in haematopoietic activity in these animals, but only in specific contamination conditions, that is, 2 and $10 \mathrm{mg} / \mathrm{L}$ of uranium in drinking water. In order to confirm a possible effect of uranium ingestion on haematopoiesis, haematopoietic progenitor frequencies were determined both in the bone marrow and in the spleen of control animals and animals contaminated with 2, 20, and $120 \mathrm{mg} / \mathrm{L}$. Results indicated that uranium ingestion did not induce a modification of progenitor frequency both in the bone marrow (Figure 3(b)) and in the spleen (data not shown). This suggested that the slight modifications in Flt3-ligand concentration observed in the plasma were not associated with a modification of haematopoiesis. Overall, these results suggest that whatever the uranium concentration in drinking water (including the highest uranium concentration of $120 \mathrm{mg} / \mathrm{L}$ ), uranium ingestion did not modify significantly blood and bone marrow parameters.

3.5. Histological Studies. Histological analysis of intestine (ileum), liver, and kidney (renal cortex) was performed in control and contaminated animals. Figure 4 showed microphotographs of histological slides from these organs, and Table 5 reported the different microscopic evaluations for the three organs considered. Concerning the small intestine (terminal ileum), no epithelial injuries were noticed (Figure 4, compare part (a) to (b)). No microscopic anomalies were identified in muscular layers, in nervous structures, or in vessels. Small intestine wall never presented inflammatory alteration or fibrosis. Gut associated lymphoid tissue (GALT) displayed normal microscopic aspect, often with some activation signs (germinal centres). Such lack of histological lesions led to a score equal to zero for intestine regardless the uranium level in drinking water. Concerning kidney microscopic evaluation, glomerular (parts (c) and (d) of the Figure 4) and tubular (parts (e) and (f) of the Figure 4) aspects were analysed. Glomerular lesions were mostly absent (Figure 4, parts (c) and (d)). Only some scattered glomerular cysts could be noticed. Tubulointerstitial lesions remained limited, with minimal to rarely mild intensity when present (Figure 4, parts (e) and (f)). These lesions consisted of multifocal inflammatory cell infiltrates, mainly composed of lymphocytes, with few plasma cells, macrophages, and rare granulocytes. Some tubules were sometimes filled with proteinaceous, eosinophilic material (hyaline casts). Interstitial fibrosis was exceptionally noticed and remained minimal, with only narrow bands of fibrous tissue thickening rare tubular basement membranes and glomerular Bowman's capsules. Tubular necrosis was never observed, whatever the group including the highest level of uranium concentration $(120 \mathrm{mg} / \mathrm{L})$. In fact, all these features were recognized in rats of either control or contaminated groups. Tubular regeneration was slightly increased in 10 and $40 \mathrm{mg} / \mathrm{L}$ groups, in comparison to control group. Tubular inflammation was slightly increased in 0.2 , 10 , and $40 \mathrm{mg} / \mathrm{L}$ groups, in comparison to control group (Table 5). Surprisingly, this increase remained very limited and was not observed in $120 \mathrm{mg} / \mathrm{L}$ group (high dose).

Histological evaluation was also performed in liver (parts (g), (h), (i), and (j) of the Figure 4 and Table 5). Almost all the rats presented inflammatory cell infiltrates into hepatic parenchyma, which always remained minimal and were mainly composed of lymphocytes (mononuclear cells), with few plasma cells, some macrophages, and rare granulocytes. They could be localized in portal areas connective tissue (portal inflammation, Figure 4, part (g)) or appear as scattered and small cellular aggregates slightly distending sinusoids (intralobular inflammation, Figure 4, part (h)). These features were recognized in rats of either control or contaminated groups. Portal necrosis was never observed, whatever the group. Cytoplasmic macrovacuolation was quite regularly observed, with minimal to moderate intensity when present (Figure 4, parts (i) and (j)). Altered hepatocytes displayed in their cytoplasm small vacuoles about 3 to $5 \mu \mathrm{m}$ in diameter, rounded, well-delimited, with empty lumen. Vacuoles were usually found in small numbers in hepatocytes. Cytoplasmic macrovacuolation was increased in contaminated groups in comparison to control group, particularly in 40 and $120 \mathrm{mg} / \mathrm{L}$ groups (Figure 4, part (j)), which suggests that it was related to uranium contamination (Table 5). One-way ANOVA analysis indicates a statistical significant difference between groups $(P<0.05)$.

3.6. Intestinal Immune System. Immune cell composition of lamina propria was investigated after a 9-month chronic ingestion of uranium. This study was performed on neutrophils, macrophages, and mast cells, all of them involved in innate immunity. Figure 5 shows the effects of uranium on the three selected immune cells after $0.2,2,20$, and $120 \mathrm{mg} / \mathrm{L}$, as compared with control group (NC: noncontaminated). These results indicated that number of immune cell populations did not vary after 9 months of uranium exposure, at any 


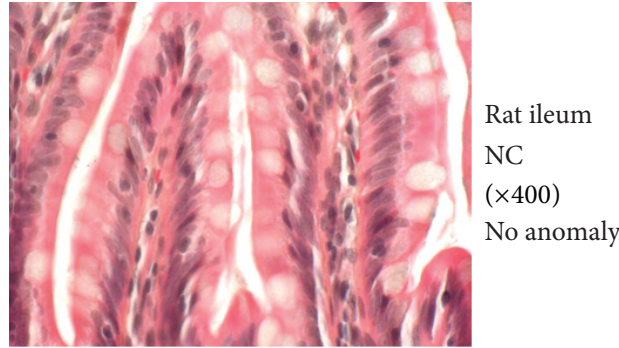

(a)

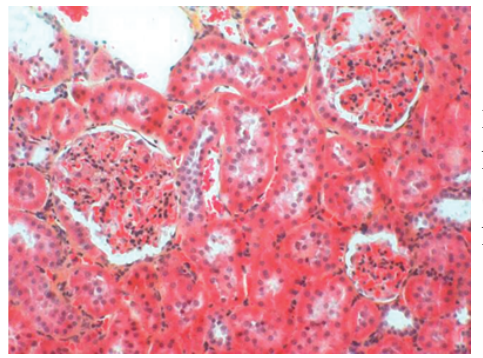

(c)

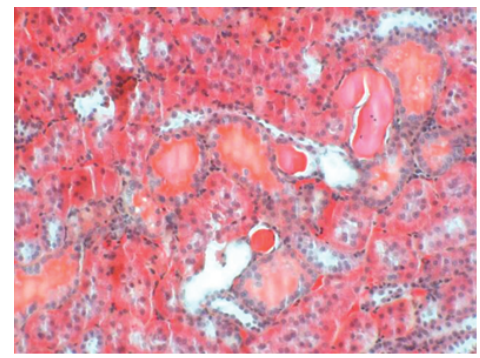

(e)

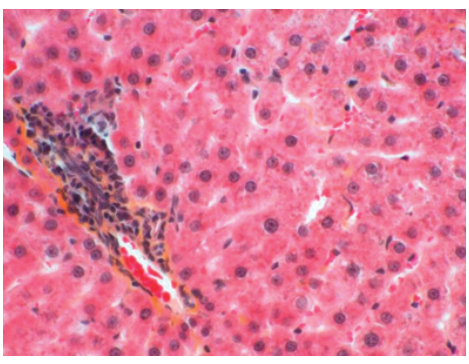

(g)

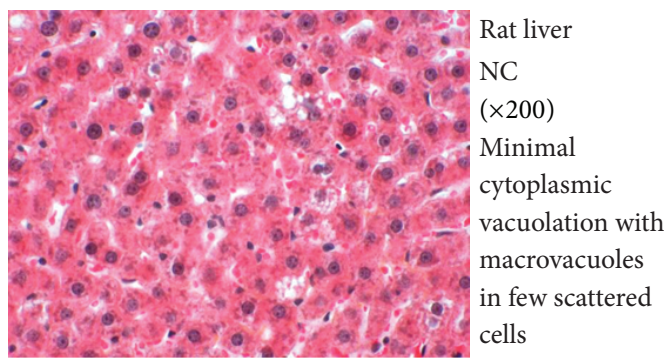

(i)

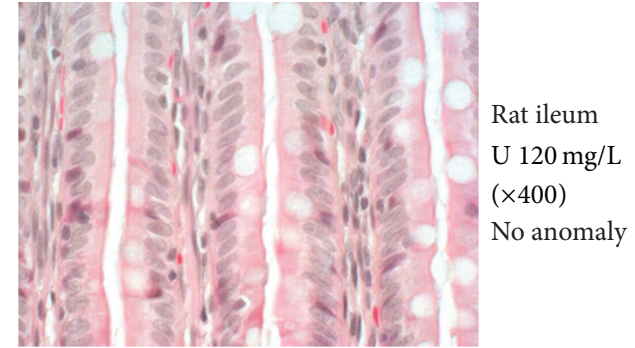

(b)

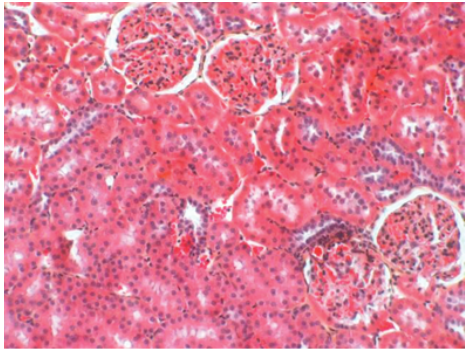

Rat kidney

$\mathrm{U} 120 \mathrm{mg} / \mathrm{L}$

$(\times 100)$

Normal glomeruli

(d)

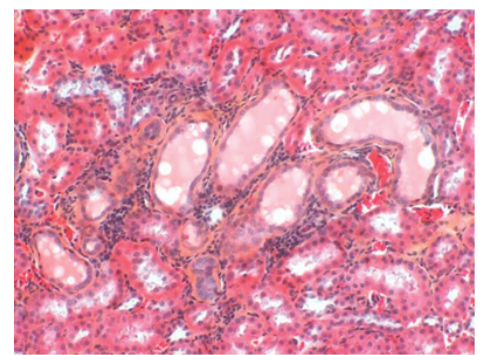

Rat kidney

$\mathrm{U} 120 \mathrm{mg} / \mathrm{L}$

$(\times 100)$

Occasional

tubular dilation

(f)

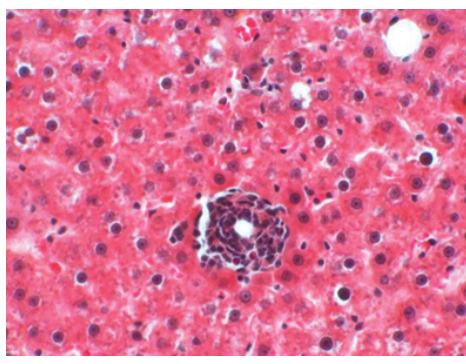

Rat liver

$\mathrm{U} 120 \mathrm{mg} / \mathrm{L}$

$(\times 200)$

Minimal

intralobular

inflammation

(h)

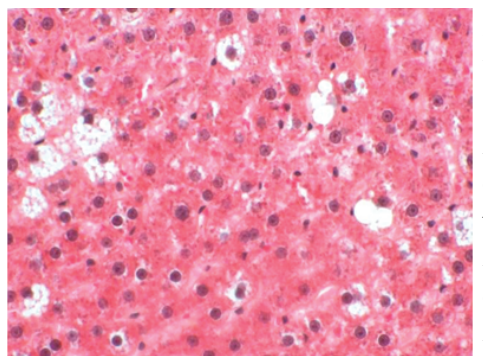

Rat liver
U $120 \mathrm{mg} / \mathrm{L}$
$(\times 200)$
Moderate
cytoplasmic
vacuolation with
many foci of
cellular
macrovacuolation

(j)

FIGURE 4: Histological alterations of intestinal, renal, and hepatic sections in rats receiving uranium at $120 \mathrm{mg} / \mathrm{L}$ in drinking water for 9 months. Microphotographs of rat tissues were obtained from control (NC: noncontaminated) and contaminated rat (120 mg/L uranium in drinking water). Sections were stained with hematoxylin-eosin-saffron. ((a), (b)) Intestinal longitudinal sections of rat ileum. ((c)-(f)) Histological sections of renal cortex. ((g)-(j)) Liver sections. 


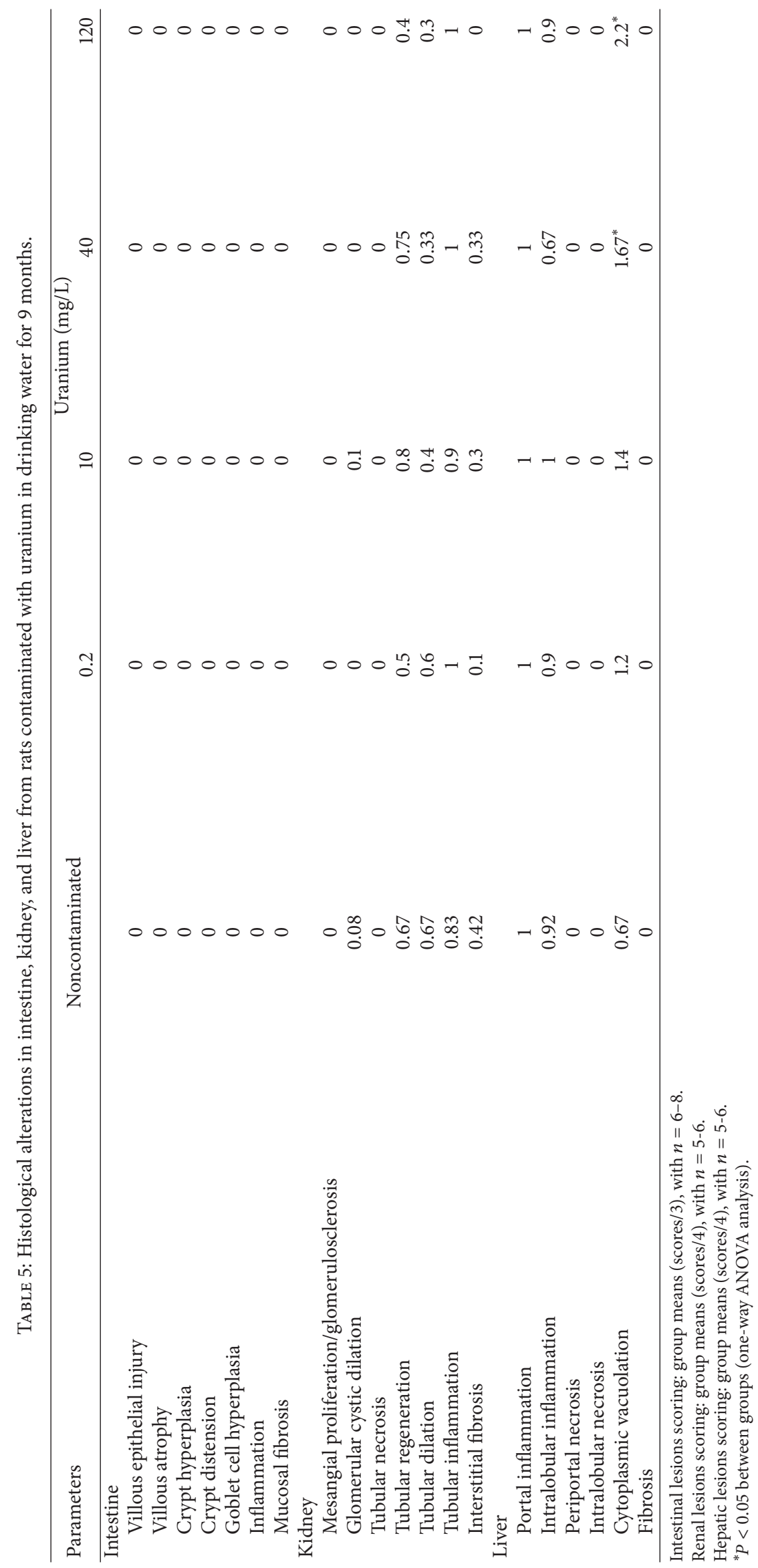



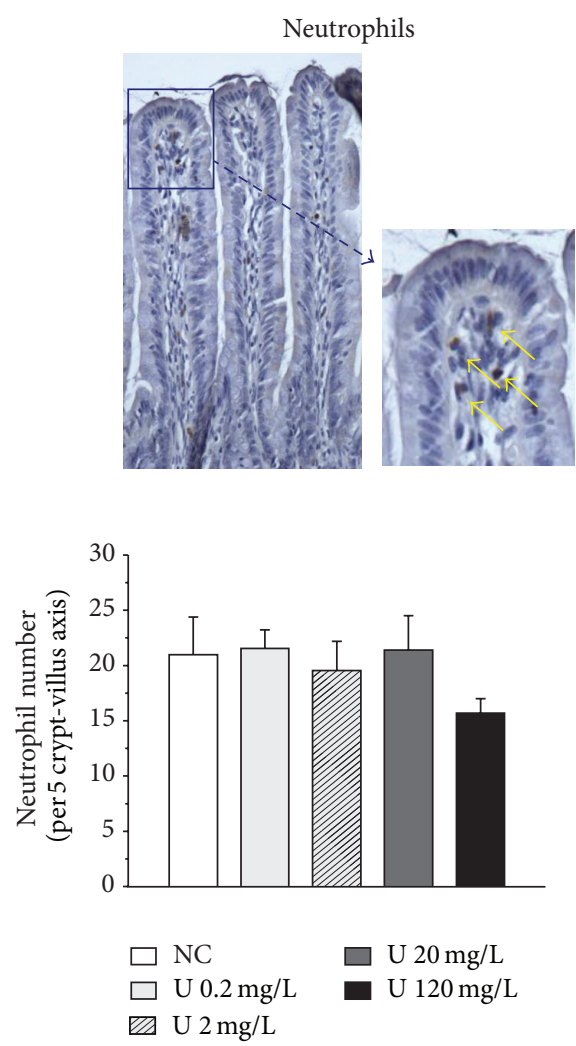

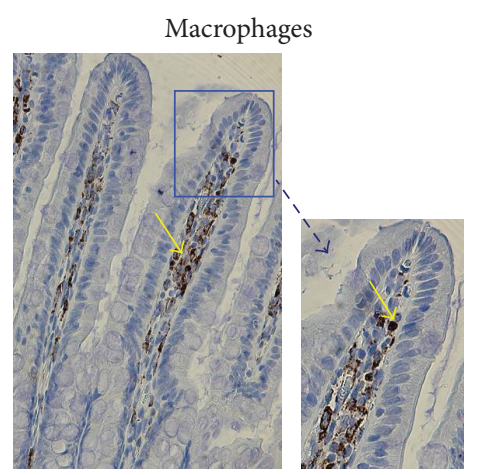

(a)
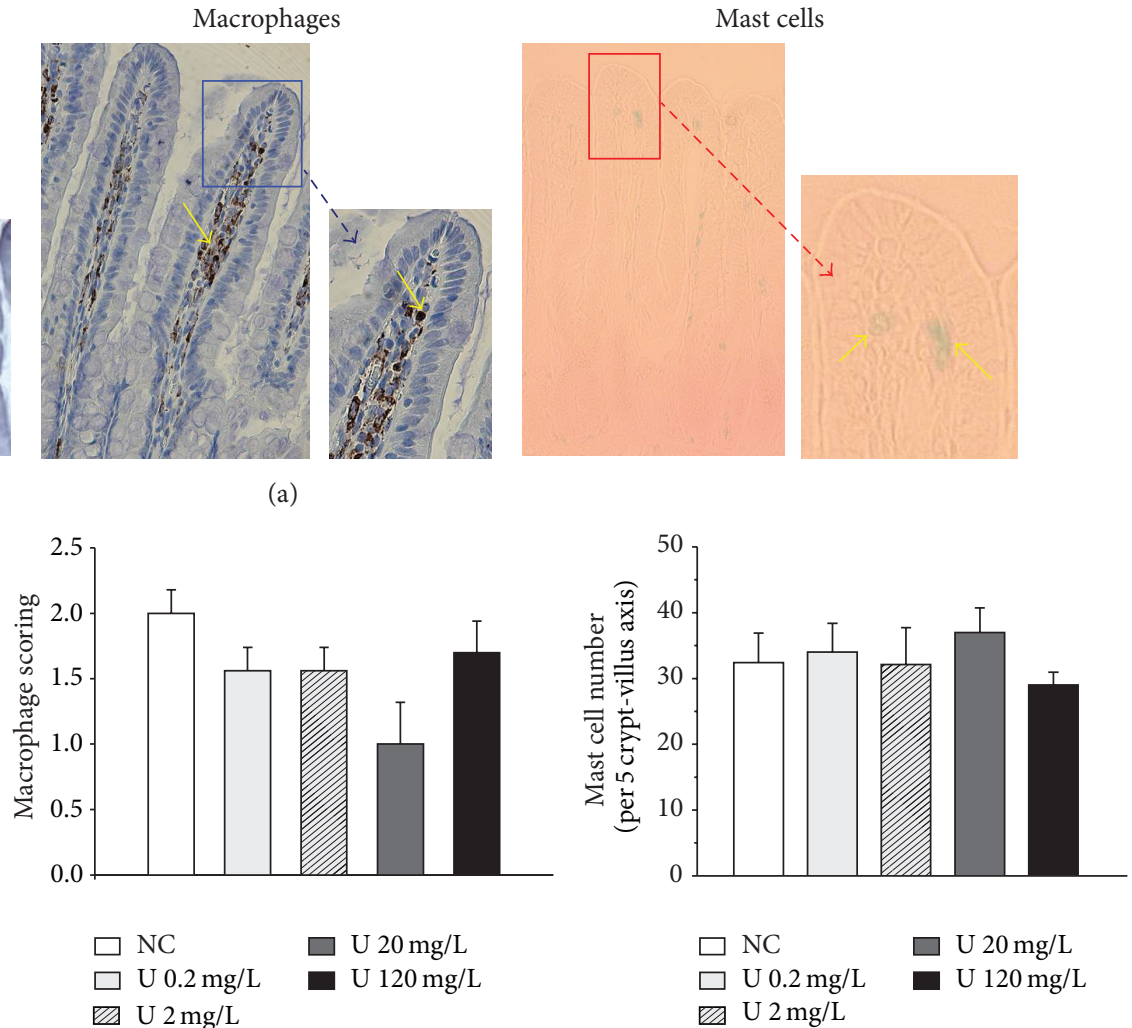

(b)

Figure 5: Effects of chronic uranium ingestion on immune cells in the intestinal mucosa in rats receiving contaminated drinking water during 9 months. Micrographs were obtained from control animals (objective $\times 20$ and $\times 40$ ). The brown staining indicates the cells positive for CD68 (macrophages) and for MPO (myeloperoxidase, neutrophils). Mast cells were stained with Alcian Blue technique. The positive cells were estimated per 5 villus-crypt axes, along the 60 measurements per animal, in control animals (NC: noncontaminated) and in animals contaminated with uranium $(\mathrm{U})$ in their drinking water at various concentrations $(0.2,2,20$, or $120 \mathrm{mg} / \mathrm{L})$. Data were mean \pm SD of 8 rats. There is no significant difference between control and experimental groups.

exposure level (from 0.2 to $120 \mathrm{mg} / \mathrm{L}$ ). The neutrophil and mast cells number in lamina propria remained constant, even at the highest level $(120 \mathrm{mg} / \mathrm{L})$. Concerning macrophages, a decrease in its network in lamina propria seemed to be induced by uranium exposure, with a diminution of $50 \%$ at $20 \mathrm{mg} / \mathrm{L}$. However, this decrease was not significant $(P=$ $0.069)$.

To complete this cellular study, effects of uranium were investigated on cytokine and chemokine content in small intestinal wall. The relative mRNA level of 5 cytokines (CCL$2, \operatorname{TNF} \alpha, \operatorname{IFN} \gamma, \operatorname{TGF} \beta$, and IL-10) was studied in intestinal mucosal extracts of control rats and in rats contaminated at $0.2,2,20$, and $120 \mathrm{mg} / \mathrm{L}$. The tissue protein level was also studied for CCL-2, TNF $\alpha$, IFN $\gamma$, and IL-10. Figure 6 represents the results of gene (Figure 6, top) and protein expression (Figure 6, bottom) for CCL-2, TNF $\alpha, \operatorname{IFN} \gamma$, and IL-10. In the top part of Figure 6, we observe an increase in gene expression for the four cytokines studied, which was significant $(P<0.05)$ for uranium levels in drinking water $20 \mathrm{mg} / \mathrm{L}$ for IFN $\gamma$, IL-10, and CCL-2. Modification of TNF $\alpha$ gene expression was observed only at $120 \mathrm{mg} / \mathrm{L}$. However, this activation is not general for all cytokines because no changes were observed in the mRNA levels of TGF $\beta$ (data not shown). Experiments were then performed to determine whether these differences in mRNA levels were associated with similar differences in protein levels. The results are indicated in the part (b) of Figure 6. Contrary to cytokine mRNA expression, which increased with uranium exposure, uranium seemed to induce an inhibition of protein levels for three cytokines studied (IFN $\gamma$, IL-10, and TNF $\alpha$ ). These variations were also observed for uranium levels $>20 \mathrm{mg} / \mathrm{L}$. However, this inhibitory effect was not observed for the highest uranium level, for which a return to control values and even an overincrease were noted for three cytokines (IFN $\gamma, \mathrm{CCL}-2$, and $\mathrm{TNF} \alpha$ ).

3.7. Xenobiotic Metabolism in Liver and Kidney. Xenobiotic metabolizing enzymes (XME) were studied in the liver and kidneys, the major organs involved in detoxification. The levels of major enzymes and proteins involved in the three phases of xenobiotic metabolism, phase I (CYP 3A2, CYP2C11), phase II (GSTA2, UGT2B1), and phase III (MRP2, MDR1), were studied in control and uranium-exposed rats. Figure 7 illustrates the effects of uranium exposure on 

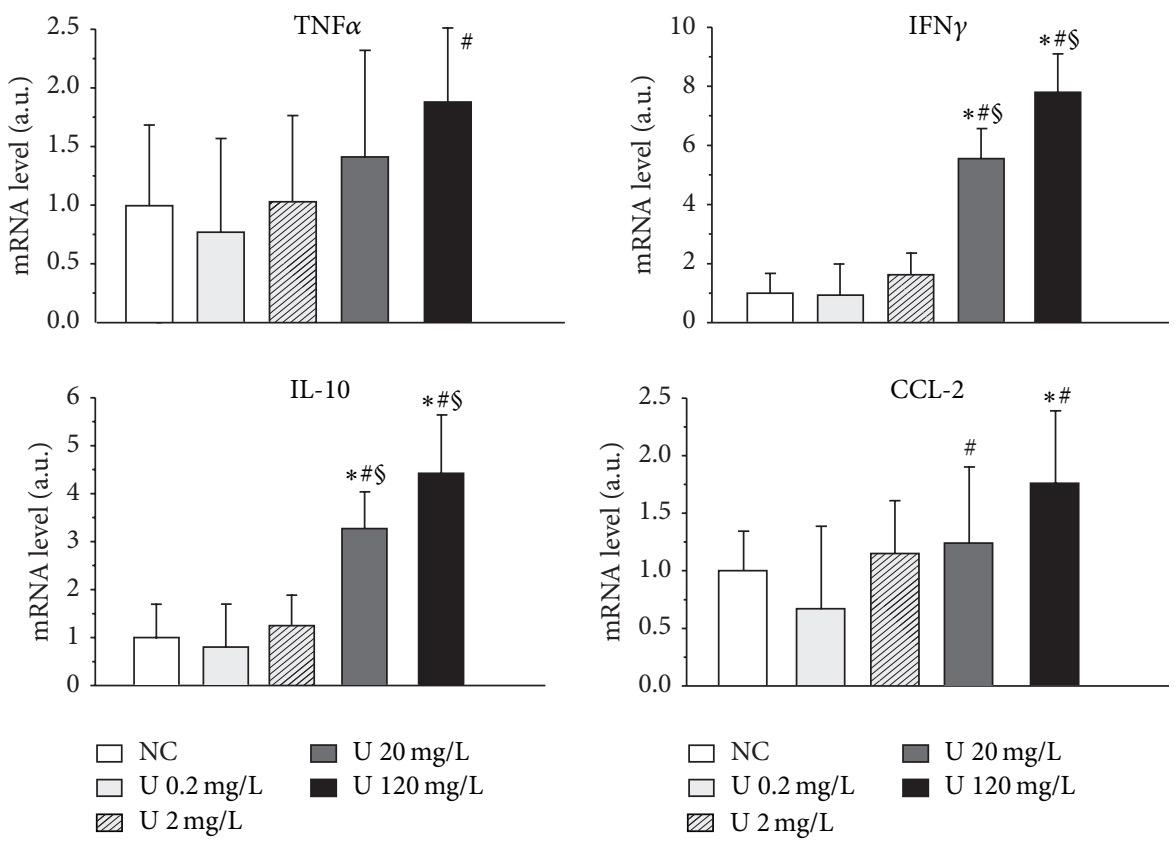

$$
\begin{array}{ll}
\square \mathrm{NC} & \square \mathrm{U} 20 \mathrm{mg} / \mathrm{L} \\
\square \mathrm{U} 0.2 \mathrm{mg} / \mathrm{L} & \mathrm{U} 120 \mathrm{mg} / \mathrm{L} \\
\square \mathrm{U} 2 \mathrm{mg} / \mathrm{L} &
\end{array}
$$

(a) Gene expression
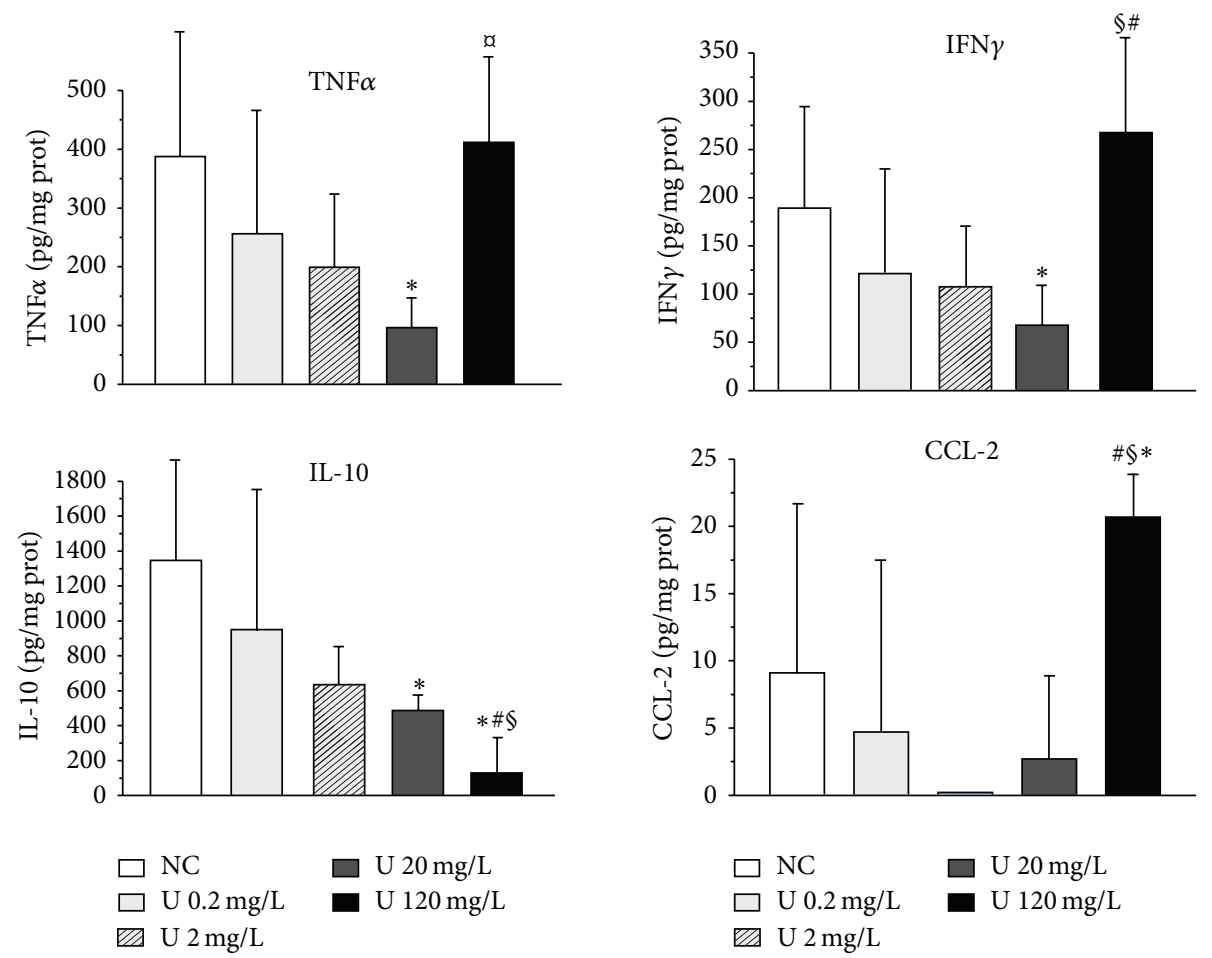

(b) Protein expression

FIGURE 6: Effects of uranium on cytokine gene and protein expression in rat intestine. Expression was measured in samples from control animals (NC: noncontaminated) and animals contaminated by uranium (U) in their drinking water at various concentrations $(0.2,2,20$, or $120 \mathrm{mg} / \mathrm{L}$ ). Data are mean \pm SD of 9-10 animals. (a) Gene expression: the mRNA levels are expressed as a ratio to the reference gene HPRT (hypoxanthine-guanine phophoribosyltransferase, a housekeeping gene). (b) Protein expression: tissue protein levels are expressed in pg/mg protein. ${ }^{*} P<0.05$ : significantly different from control values. ${ }^{S} P<0.05$ : significantly different from the $\mathrm{U} 0.2 \mathrm{mg} / \mathrm{L}$ group. ${ }^{\#} P<0.05$ : significantly different from the U $20 \mathrm{mg} / \mathrm{L}$ group. 


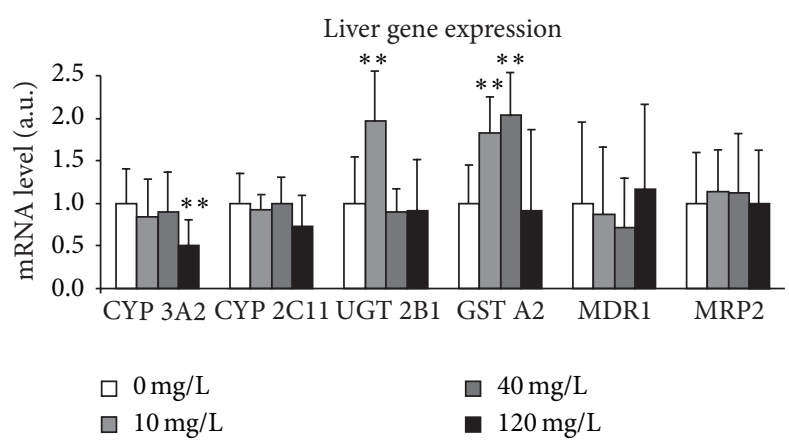

(a)

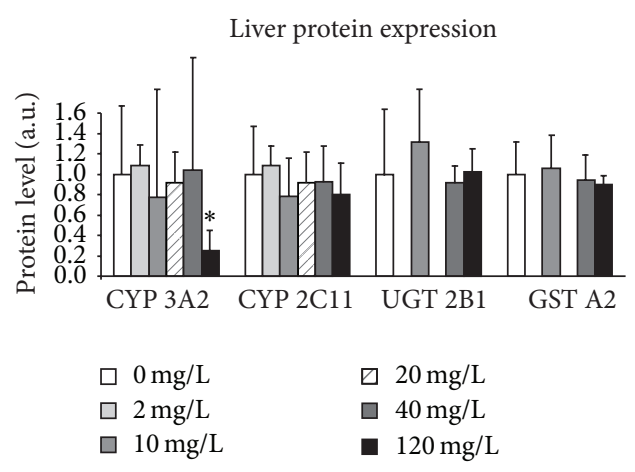

(b)

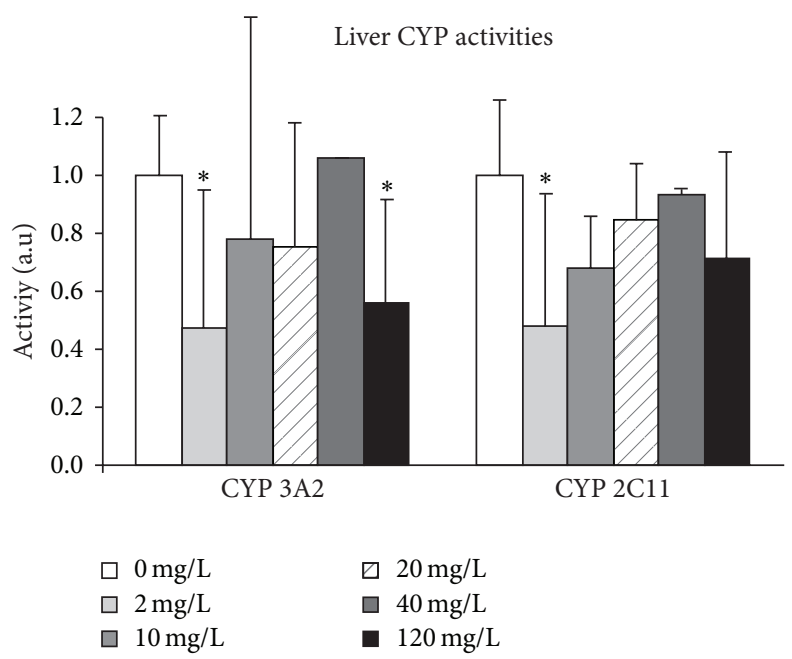

(c)

FIGURE 7: Effects of uranium on enzymes of xenobiotic metabolism in the liver. The molecules of phases I, II, and III of xenobiotic metabolism were measured in control animals (NC: noncontaminated) and in animals contaminated by uranium (U) in their drinking water at various concentrations $(10,40$, or $120 \mathrm{mg} / \mathrm{L}$ ). Gene expression: the mRNA levels are expressed as a ratio to the reference gene HPRT (hypoxanthineguanine phophoribosyltransferase, a housekeeping gene). Data are mean \pm SEM of 8 animals. Protein expression: protein levels are expressed as a ratio to the reference gene GAPDH (glyceraldehyde 3-phosphate dehydrogenase, a housekeeping gene). Data are mean \pm SD of 8 animals. CYP activities: enzyme activities are expressed in picomoles per minute per whole liver and values are normalized to the noncontaminated group. Data are mean \pm SD of 6 animals. ${ }^{*} P<0.05$ : significantly different from control values. ${ }^{* *} P<0.01$ : significantly different from control values.

cytochrome P450, expressed mainly in the liver. Some variations of enzyme activity were observed starting from $2 \mathrm{mg} / \mathrm{L}$ of uranium in drinking water, that is, for CYP3A2 $(-53 \%, P<$ $0.05)$ and CYP2C11 (-52\%, $P<0.05)$ (Figure 7(c)), but these effects were not observed at the mRNA and protein levels. By contrast, gene expression of phase II enzymes was modified at 10 (GSTA2, UGT2B1) and $40 \mathrm{mg} / \mathrm{L}$ (GSTA2) (data not shown). It appears that $120 \mathrm{mg} / \mathrm{L}$ induced major effects, since a drastic decrease in CYP3A2 was observed concomitantly in the levels of mRNA $(-50 \%, P<0.01)$, protein $(-75 \%, P<$ $0.05)$, and enzyme activity $(-44 \%, P<0.05)$ in the rat liver. This indicated that uranium exposure at this concentration altered a major enzyme of the xenobiotic system which could impact the detoxification function in the liver.

To determine if uranium also targets this detoxification system in the kidneys, the classical storage and target organ of this radionuclide, XME (CYP 3A2 and CYP2C11 for phase I, UGT2B1, GSTA2, and ST1A1 for phase II, and MDR1 and
MRP2 for phase III), was studied in the renal cortex. Figure 8 shows that there was no effect on several phase I (CYP 3A2, CYP2C11) and II (UGT2B1, GSTA2) enzymes. Thus, in contrast to the results observed in liver, this figure indicates that renal mRNA (Figure $8(\mathrm{a})$ ) and protein (Figure $8(\mathrm{~b})$ ) levels of CYP3A2 did not change in the kidneys of rats exposed to uranium, at any exposure level. Moreover, there were no changes in UGT2B1 and GSTA2 phase II enzymes, which are more abundant in the kidneys than phase I enzymes. Only an increase, apparently dose-dependent, in STA1 gene expression was observed from $10 \mathrm{mg} / \mathrm{L}$.

3.8. Cholesterol Metabolism in Liver. To complete the evaluation of liver function, we investigated the different steps of cholesterol metabolism in the liver (biosynthesis, catabolism, storage, transport, and regulation). The gene expressions of enzymes and transcription factors involved 


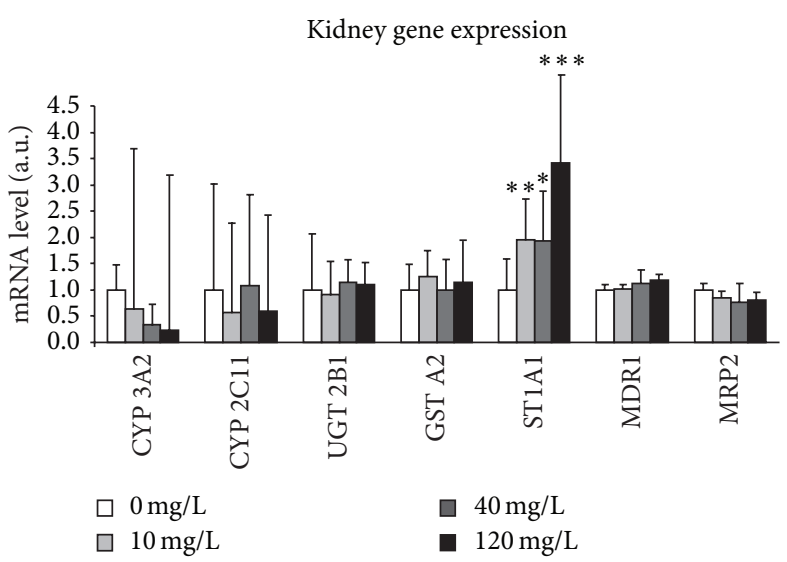

(a)

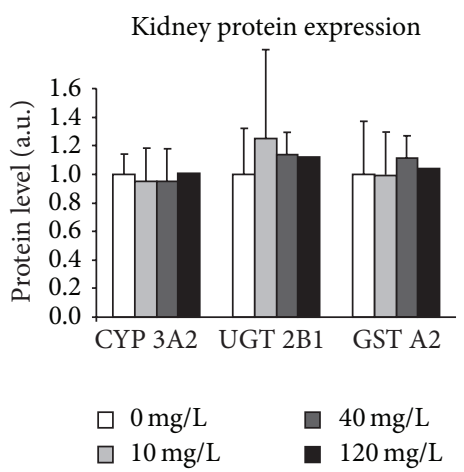

(b)

FIGURE 8: Effects of uranium on enzymes of xenobiotic metabolism in the kidneys. The molecules of phases I, II, and III of xenobiotic metabolism were measured in control animals (NC: noncontaminated) and in animals contaminated by uranium in their drinking water at various concentrations $(10,40$, or $120 \mathrm{mg} / \mathrm{L})$. Gene expression: the mRNA levels are expressed as a ratio to the reference gene HPRT (hypoxanthine-guanine phophoribosyltransferase, a housekeeping gene). Data are mean \pm SD of 8 animals. Protein expression: protein levels are expressed as a ratio to the reference gene GAPDH (glyceraldehyde 3-phosphate dehydrogenase, a housekeeping gene). Data are mean \pm SD of 6 animals. ${ }^{*} P<0.05,{ }^{* *} P<0.01$ : significantly different from control values. ${ }^{* * *} P<0.001$ : significantly different from control values.

in this metabolism in the liver of control and contaminated animals with uranium at $0.2,20,40$, and $120 \mathrm{mg} / \mathrm{L}$ were indicated in Figure 9. Any modification was noted for the biosynthesis step. Concerning the catabolism step of cholesterol metabolism, the results show that uranium affected the relative mRNA level of CYP27A1 in the $120 \mathrm{mg} / \mathrm{L}$ group $(+31 \%$, Figure 9$)$. This highest level of uranium induces also an increase in gene expression of some molecules involved in storage (ACAT2, $+70 \%$ ), in storage (ABCA1, +70\%), and in regulation (LXR, RXR, and SREBP2, between 30 and 40\%) processes.

These results were completed by measurement of enzyme activity of the two major cytochrome P450 of type 27A1 (CYP27A1) and 7A1 (CYP7A1) (Figure 10). No change was observed for CYP27A1, but uranium affected the activity of CYP7A1 (by a multiple of 6.5, Figure 10).

3.9. Cholinergic Pathway in the Entorhinal Cortex. The cholinergic system in the brain (entorhinal cortex) was examined to investigate the molecular effects of uranium that might underlie central nervous system dysfunction. Figure 11 illustrates the results obtained after a 9-month contamination. Chronic ingestion of uranium did not modify acetylcholine content in the cortex at any exposure level. We did, however, note a dose-independent diminution of acetylcholinesterase activity after uranium contamination $(-15 \%)$.

3.10. Antioxidant Enzymes in the Entorhinal Cortex. Because oxidative stress is a potential mechanism of uranium neurotoxicity, we investigated the effects of uranium on the brain by studying antioxidant defenses. Uranium affected each enzyme studied, but at different thresholds and in opposite directions (Figure 12). It induced a slight increase in catalase activity $(+20 \%$ at $120 \mathrm{mg} / \mathrm{L})$ and GSH content $(+20 \%$ at $2 \mathrm{mg} / \mathrm{L}$ ) and a dose-dependent activation effect on glutathione peroxidase $(+68 \%$ at $2 \mathrm{mg} / \mathrm{L}$ and $+90 \%$ at $120 \mathrm{mg} / \mathrm{L})$. On the other hand, it inhibited superoxide dismutase activity at all uranium concentrations, in a dose-independent manner $(\sim-50 \%)$.

\section{Discussion}

The primary objective of this experimental study was to obtain new data to improve our knowledge of the longterm effects of uranium chronically ingested in drinking water. More specifically, the purpose of this work was to (i) determine the possible thresholds for functional (molecular or cellular) and for pathological (tissue and general health) effects of uranium and (ii) establish the differential sensitivity of the different organs to uranium. The strength of the present study lies in its combination of a wide range of uranium levels $(0.2,2,5,10,20,40$, or $120 \mathrm{mg} / \mathrm{L})$, a large panel of target organs (the small intestine, liver, kidneys, hematopoietic tissue, and brain), and complementary levels of biological analyses (molecular, functional, structural, and pathological).

Concerning the intestines, a uranium accumulation was previously demonstrated in the lamina propria of intestinal wall, near the immune cells [26] and in Peyer's patches [27], a site specialized in the immune response of the small intestine against pathogens. The objective of the present study was thus to investigate uranium effects on immune function of intestinal mucosa due to this specific localization of uranium. The kidneys and the liver are the major organs involved in detoxification processes of endo- and xenomolecules, which constitute in return the primary function of these organs. Thus, the present investigation of uranium effects on the kidneys and the liver was based on the different phases of the xenobiotic metabolism. In addition, cholesterol metabolism 


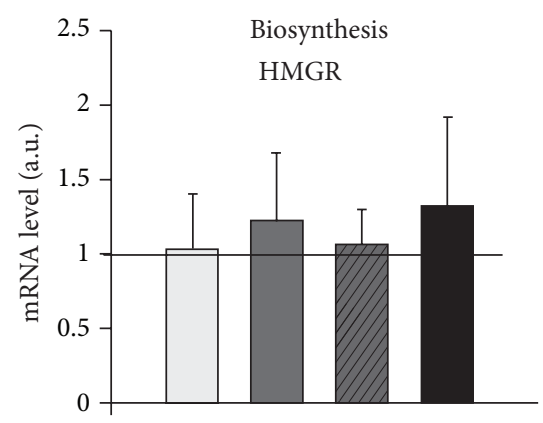

(a)

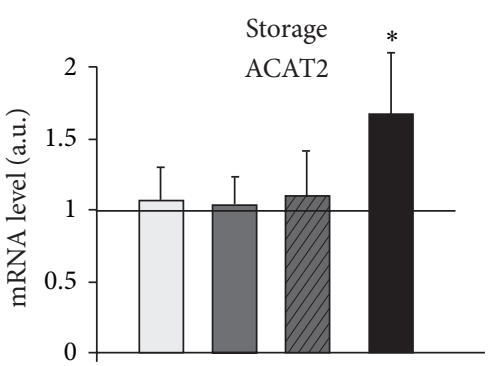

(c)

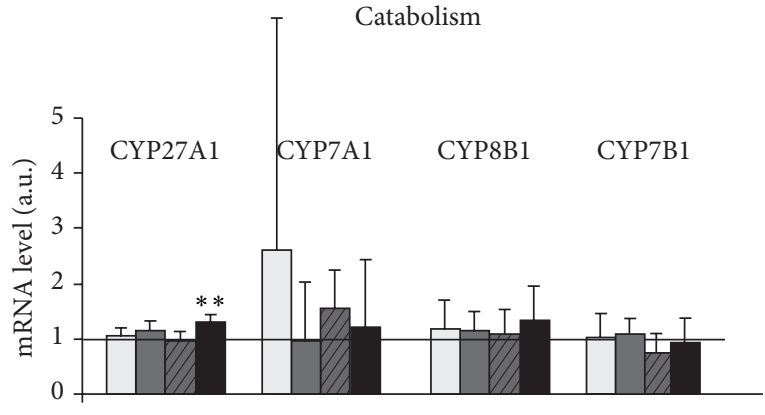

(b)

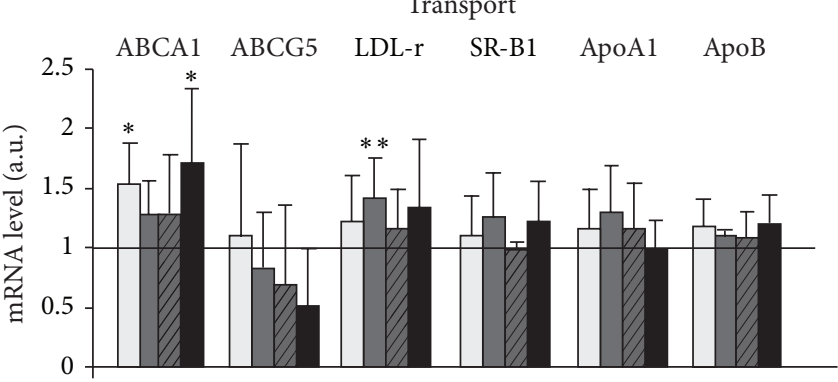

(d)

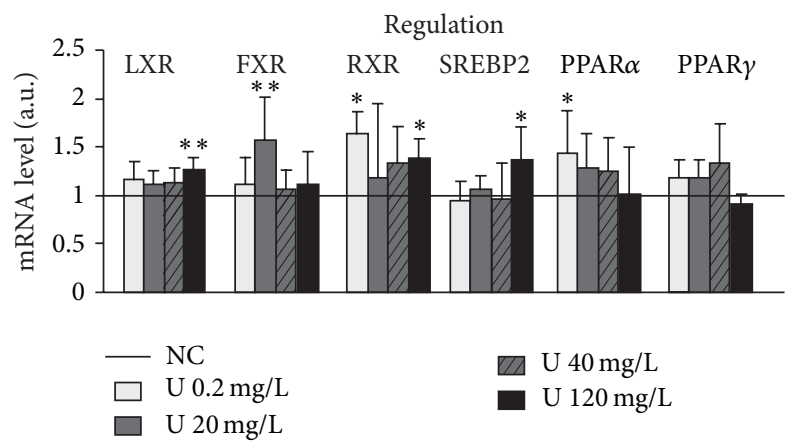

(e)

FIGURE 9: Effects of uranium on gene expression of enzymes of cholesterol metabolism in the liver. The gene expressions were measured in control animals (NC: noncontaminated) and in animals contaminated by uranium in their drinking water at various concentrations $(0.2,20$, 40 , and $120 \mathrm{mg} / \mathrm{L}$ ). The mRNA levels are expressed as a ratio to the reference gene HPRT (hypoxanthine-guanine phophoribosyltransferase, a housekeeping gene). Data are mean \pm SD of 8 animals. ${ }^{*} P<0.05,{ }^{* *} P<0.01$ : significantly different from control values.

was studied in the liver, since this organ plays the central role in whole organism concerning this metabolism. The effects of uranium on the central nervous system were evaluated via two mechanisms, the uranium-induced oxidative stress and the cholinergic system. Indeed, a possible mechanism of uranium effects observed in cognitive functions may be due to the oxidative stress induced by reactive oxygen species imbalance [30]. A uranium-induced chronic cerebral oxidative stress may have subsequent consequences on brain function, with possible development of neurological disorders [39]. Effects of uranium on cholinergic system may lead to impairment in learning and attention [40] or promote neurodegenerative pathologies such as Alzheimer's disease. Finally, effects induced by uranium were measured in hematopoietic cells, since uranium accumulated in the bones and kidneys following chronic contamination [25, 41].
As indicated above, this study investigated several parameters of specific function(s) of all organs considered, to ensure the absence of possible consequences of uranium exposure on them. The present study did demonstrate that uranium induces some effects at the molecular level on the five considered organs.

Investigation of cholesterol metabolism in the liver indicated variations of mRNA levels for the molecules involved, but most uranium-induced effects were noted at $120 \mathrm{mg} / \mathrm{L}$ and led to minor modifications in catabolism, storage, transport, and regulation processes. These results indicate that uranium targets cholesterol metabolism at mRNA level, as previously reported [42]. Nevertheless, these biological effects were not harmful as they had no impact on the plasma lipid profile. Concerning the liver xenobiotic metabolism, some slight effects on mRNA levels were reported at low 


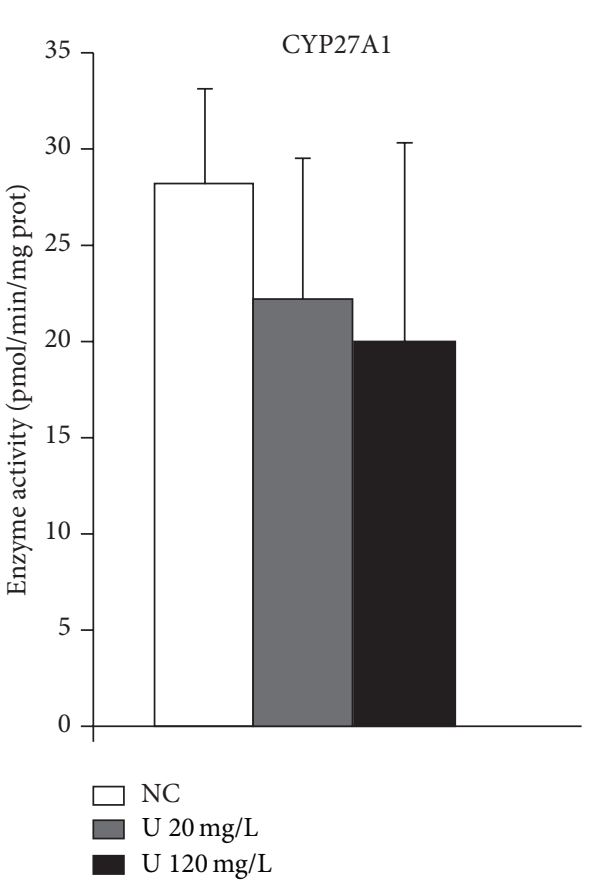

(a)

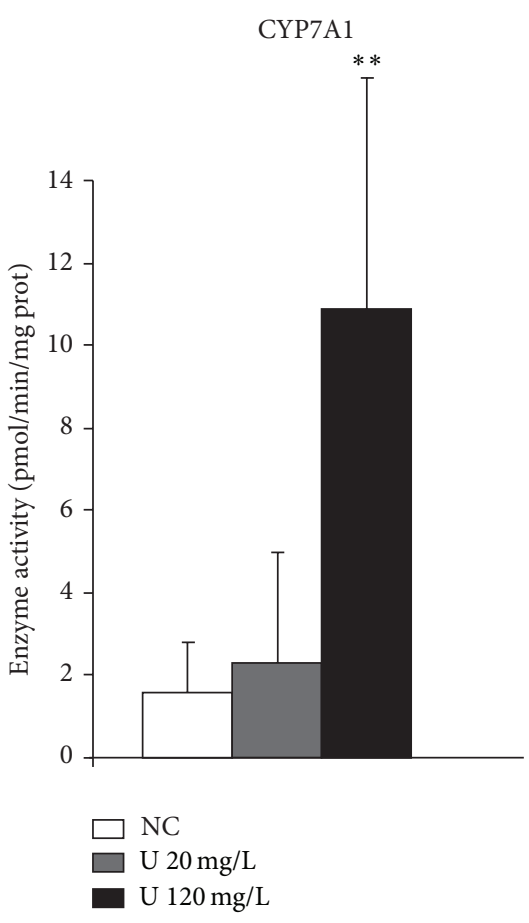

(b)

FIGURE 10: Effects of uranium on enzyme activity of enzymes of cholesterol metabolism in the liver. Enzyme activity is expressed as picomoles per minute per milligram total protein. Data are mean \pm SEM of 6 animals. ${ }^{* *} P<0.01$ : significantly different from control values.

exposure $(2 \mathrm{mg} / \mathrm{L})$ and more important effects (mRNA, proteins, and activity) on a specific enzyme (CYP3A) with a greater variation at high exposure $(120 \mathrm{mg} / \mathrm{L})$. These results supplemented previous studies of xenobiotic metabolism in the liver $[23,36]$. Surprisingly, the present study did not observe these effects on xenobiotic metabolism in the kidney, the organ considered most sensitive to uranium. This lack of molecular effects on the kidneys is in accordance with previous results obtained by Linares et al., which demonstrated induction of oxidative stress only at uranium levels above $400 \mathrm{mg} / \mathrm{L}$ [43]. In the small intestine, changes of protein and mRNA tissue levels of cytokines were observed for medium $(20 \mathrm{mg} / \mathrm{L})$ and high $(120 \mathrm{mg} / \mathrm{L})$ uranium levels, demonstrating effect of uranium on inflammatory mediators in the intestines, corroborating the hypothesis that the intestinal system may be a biological target of uranium following ingestion. However, these variations should not be considered adverse effects, given that the number of immune cells in the intestinal mucosa did not change significantly. The only change was a nonsignificant $50 \%$ diminution of macrophages, as mentioned previously [20]. Biological effects of uranium on the brain were estimated by investigating the cholinergic pathway and oxidative stress. For the former, a non-dose-dependent reduction in acetylcholinesterase activity began at $0.2 \mathrm{mg} / \mathrm{L}$, the lowest exposure level. Such decreased acetylcholinesterase activity was already reported [38]. Modifications of the activity of antioxidant enzymes were also observed at that level. At higher exposures $(2,20$, and $120 \mathrm{mg} / \mathrm{L}$ ), the activity of 3 enzymes (of the 4 studied) was modified. Other recent studies have reached the same conclusions, reporting opposite effects by uranium on the antioxidant status of the brain, depending on radiological activity [30] and uranium levels [44]. As for the other organs, these modifications need not be considered deleterious, since both antioxidant enzyme activity and acetylcholine levels were not reduced in the brain. Finally, no real damages to hematopoiesis were observed. This finding suggests that the slight modifications of the Flt3-ligand concentration in the blood were not linked to a major modification of hematopoietic activity.

Overall, these results indicate that uranium ingestion is able to induce subtle but significant effects at the molecular level, mainly on mRNA expression, which does not have any deleterious consequences.

Different thresholds may be deduced on the basis of these observed molecular effects: $20 \mathrm{mg} / \mathrm{L}$ for the intestine, $>10 \mathrm{mg} / \mathrm{L}$ for the kidneys, $>2 \mathrm{mg} / \mathrm{L}$ for the liver, and only $0.2 \mathrm{mg} / \mathrm{L}$ for the brain. This indicates that the kidneys are not the organ the most sensitive to chronic contamination by uranium ingestion. The brain appears very sensitive, as several previous studies have shown [44-46]. At high doses, uranium may induce adverse effects including impairment of memory [47] and locomotion [45]. Surprisingly, these results demonstrated that there is no clear positive relationship between uranium accumulation and its biological effects. Indeed, this relation appeared to be an inverse one: the organs the most affected by uranium exposure were those that did not accumulate it $(1 \mathrm{ng} / \mathrm{g}$ in brain, $2.5 \mathrm{ng} / \mathrm{g}$ in 


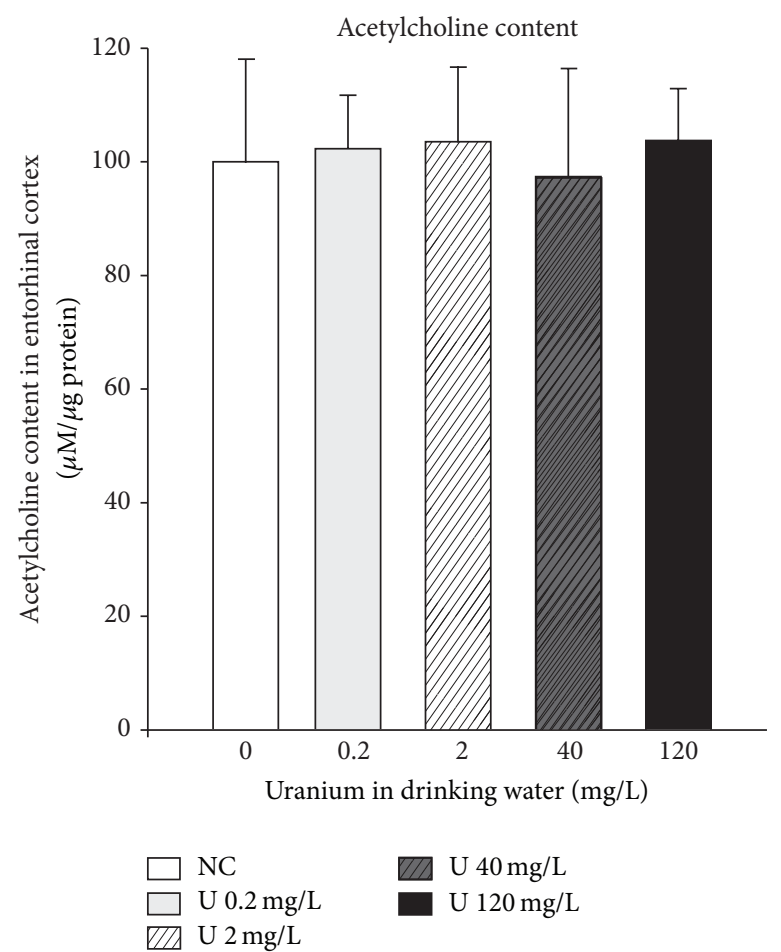

(a)
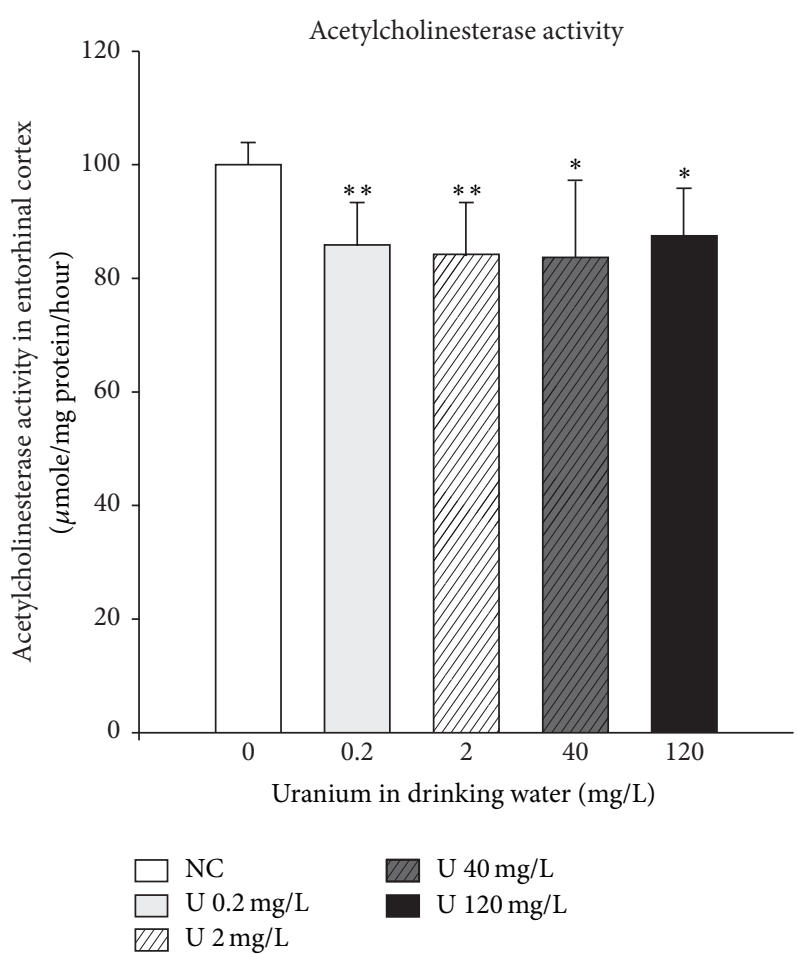

(b)

FIGURE 11: Effect of chronic ingestion of uranium on cholinergic pathway in the entorhinal cortex. The measurements were measured in control animals (NC: noncontaminated) and in animals contaminated by uranium in their drinking water at various concentrations $(0.2,2$, $20,40$, and $120 \mathrm{mg} / \mathrm{L})$. Results are expressed as mean $\pm \mathrm{SD}(n=8-10) .{ }^{*} P<0.05,{ }^{* *} P<0.01$ : significantly different from control values.

liver, and $350 \mathrm{ng} / \mathrm{g}$ in kidney, at $120 \mathrm{mg} / \mathrm{L}$ ). These values are consistent with data of previous studies that indicated no real accumulation of uranium in central nervous system following chronic contamination with uranium [30,48].

Such observation was confirmed in other organs, namely, gonads. Indeed, very low quantities of uranium were measured in ovaries $[49,50]$ and testis [43], when uranium effects were observed on reproductive function. This finding shows the special sensitivity of the brain or the gonads to chemical toxicity by metals, notably uranium [51].

Another noteworthy point about the observations in this study is the shape of the dose-response relations. Although we might have expected increased classical dose-response curves, we found also that uranium contamination elicited U-shaped or inverted U-shaped curves. Such nonmonotonic shapes have previously been described following chronic lowdose uranium contamination. A kinetic study performed during a chronic ingestion of uranium in drinking water showed successive waves of uranium accumulation and elimination depending on the time exposure [48]. Nonmonotonic curves were also observed with uterine parameters depending on uranium levels [52]. Two nonexclusive hypotheses may be proposed. Firstly, it can be assumed that uranium may inhibit or activate the concerned genes depending on the dose. Secondly, the number and the role of molecular targets for uranium may vary with exposure levels, modifying thus the whole response of the organ. Only the elucidation of the underlying mechanisms of uranium effects following a chronic exposure to low level could reply to these queries. Besides, the nonmonotonic form of these dose-response relations raises the problem of their use for the possible establishment of guidelines [53].

The second major information of the present study concerns the nondeleterious effects induced by uranium. This present study demonstrates clearly that chronic ingestion of uranium at environmental exposures $(\leq 2 \mathrm{mg} / \mathrm{L})$ and higher (up to $120 \mathrm{mg} / \mathrm{L}$ ) did not produce harmful effects in rats, as evidenced by the absence of clinical signs and histological lesions in all the organs we studied. Our study observed only a trend toward minor uranium-induced histological impairment, specifically, increased cytoplasmic vacuolation in the liver. Gilman and his colleagues reported also this minor histological alteration in the kidneys and in the liver at all uranium exposure levels [19]. The lack of adverse histological lesions in the kidneys is in accordance with the absence of changes of urea and creatinine in blood, traditionally considered as bioindicators of a renal dysfunction. The primary site of accumulation and subsequent effects of uranium in the kidneys was the proximal tubule cells as observed with other metals [54]. Specific biomarkers of proximal tubule function were not analyzed in this study, but a recent study [36] failed to evidence a change of Kim-1, kallikrein, and osteopontin levels following a chronic exposure to uranium with a contamination protocol (9 months 


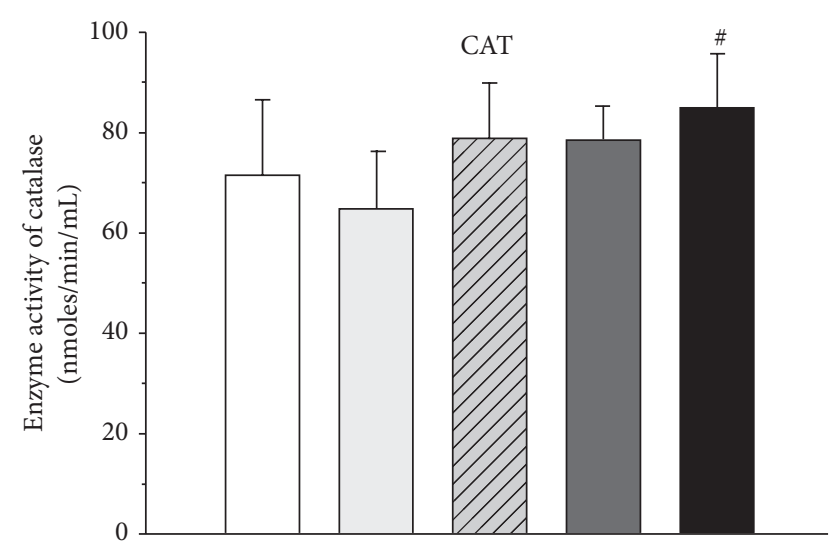

(a)

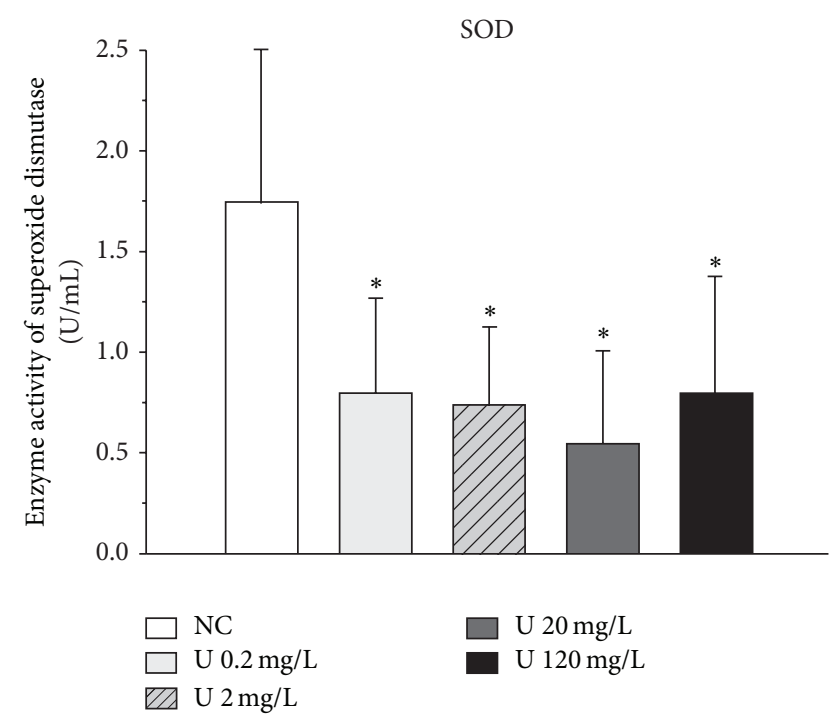

(c)

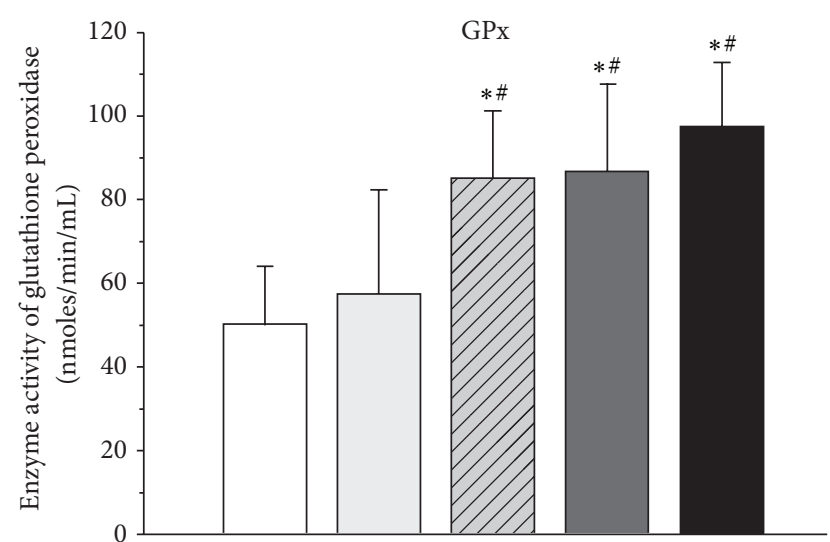

(b)

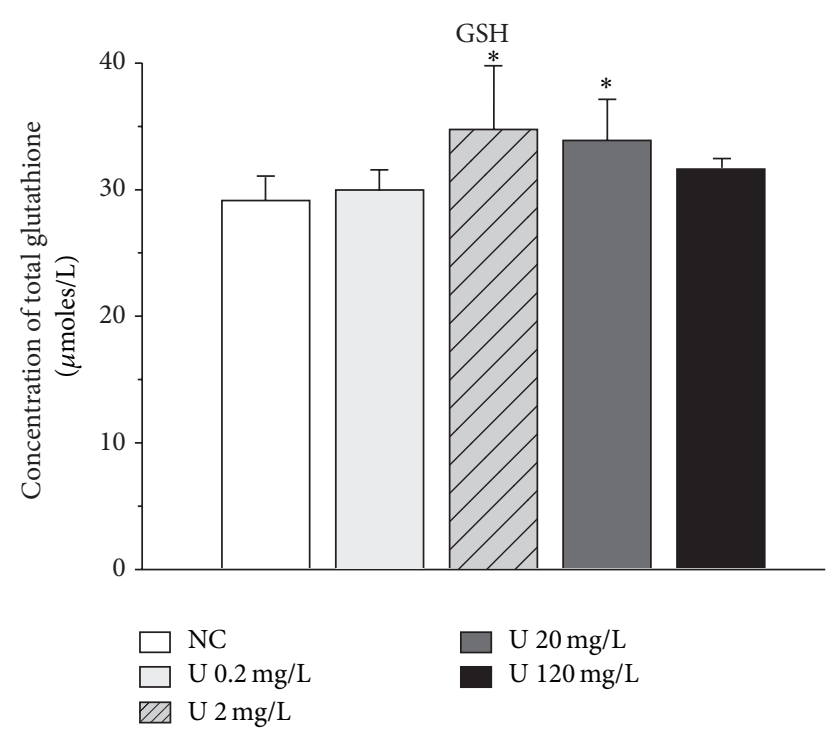

(d)

FIGURE 12: Effect of chronic ingestion of uranium on antioxidant enzyme activity in the entorhinal cortex. Three enzymes were measured, catalase (CAT), glutathione peroxidase (GPx), and superoxide dismutase (SOD), as well as total glutathione (GSH). NC: noncontaminated animal. Results are expressed as mean $\pm \operatorname{SEM}(n=8) .{ }^{*} P<0.05,{ }^{* *} P<0.01$ : significantly different from control values. ${ }^{\#} P<0.05$ : significantly different from the U $0.2 \mathrm{mg} / \mathrm{L}$ group.

with $40 \mathrm{mg} / \mathrm{L}$ ) similar to this used in the present study. This point strengthens the absence of marked uranium effects in the kidneys even at high level. In fact, the maximal uranium quantity measured in kidney of the present study following a chronic exposure at the highest level corresponded to 1/10 of the nephrotoxic threshold of $3 \mu \mathrm{g} / \mathrm{g}$ defined for an acute exposure [15], despite a high uranium level in drinking water. This may explained the absence of adverse effects in kidneys. Our conclusion is consistent with other reports, including the recent study by Linares et al. [43], which demonstrated only minor histological lesions for uranium exposure $>200 \mathrm{mg} / \mathrm{L}$. However, some studies are not in accordance with the present study and the studies cited above. For instance, these results are not concordant with those obtained by Gilman et al. in 1998 [19]. The objective of Gilman's study was to determine a NOAEL in rats by investigating kidney and liver after chronic ingestion of uranium-contaminated drinking water (from
0.96 to $600 \mathrm{mg} / \mathrm{L}$ ). The authors reported adverse renal lesions on tubules and glomeruli. Surprisingly, these histological lesions were observed in all contaminated groups including the lowest exposure of $0.96 \mathrm{mg} / \mathrm{L}$, independently of dose. It is noteworthy that no other experimental study has been performed at such low exposure levels. Other publications have noted histological lesions of rat kidneys, but at higher uranium exposure levels $(200 \mathrm{mg} / \mathrm{L},[43] ; 30 \mathrm{mg} / \mathrm{L}$, [55]). Recently, Homma-Takeda et al. published deleterious effects of uranium in different rat models (neonate, prepubertal, and adult) after subcutaneous administration of uranium acetate [56]. The discrepancy is very likely due to the difference of the administration mode. Indeed, previous study demonstrated that only $0.5 \%$ of uranium present in drinking water was absorbed into blood by the gastrointestinal system [57].

This lack of histopathological lesions and clinical signs was thus in accordance with the subtle biological effects 
TABLE 6: Symopsis of uranium accumulation and effects in rats contaminated with uranium in drinking water for 9 months.

\begin{tabular}{|c|c|c|c|c|c|c|c|}
\hline $\operatorname{Uranium}(\mathrm{mg} / \mathrm{L})$ & 0.2 & 2 & 5 & 10 & 20 & 40 & 120 \\
\hline Health & Type equation here. & & & & & & \\
\hline Body weight & $=$ & $=$ & $=$ & $=$ & $=$ & $=$ & $=$ \\
\hline Water consumption & $=$ & $=$ & $=$ & $=$ & $=$ & $=$ & $=$ \\
\hline Food consumption & $=$ & $=$ & $=$ & $=$ & $=$ & $=$ & $=$ \\
\hline \multicolumn{8}{|l|}{ Intestine } \\
\hline Gene expression of cytokines & $=$ & $=$ & & & $\uparrow$ & $=$ & $\uparrow$ \\
\hline Protein expression of cytokines & $=$ & $=$ & & & $\downarrow$ & $=$ & $\uparrow$ \\
\hline Immune cell number & $=$ & $=$ & & & $=$ & $=$ & $=$ \\
\hline Histology & $=$ & $=$ & & $=$ & $=$ & $=$ & $=$ \\
\hline \multicolumn{8}{|l|}{ Kidney } \\
\hline Uranium accumulation & & $\uparrow$ & $\uparrow$ & $\uparrow$ & $\uparrow$ & $\uparrow$ & $\uparrow$ \\
\hline Gene expression of EMX & & & & $\uparrow$ & & $\uparrow$ & $\uparrow$ \\
\hline Protein expression of EMX & & & & $=$ & & $=$ & $=$ \\
\hline Histology & $=$ & $=$ & $=$ & $=$ & $=$ & $=$ & $=$ \\
\hline Plasma parameters & $=$ & $=$ & $=$ & $=$ & $=$ & $=$ & $=$ \\
\hline \multicolumn{8}{|l|}{ Liver } \\
\hline Uranium accumulation & $=$ & $=$ & $=$ & $=$ & $\uparrow$ & $\uparrow$ & $\uparrow$ \\
\hline Gene expression EMX & & & & $\uparrow$ & & $\uparrow$ & $=$ \\
\hline Protein expression EMX & & $=$ & & $=$ & $=$ & $=$ & $\downarrow$ \\
\hline Enzyme activity EMX & & $\downarrow$ & & $=$ & $=$ & $=$ & $\downarrow$ \\
\hline Gene expression Chol Met & $=$ & & & & $=$ & $=$ & $\uparrow$ \\
\hline Enzyme activity Chol Met & & & & & $=$ & & $\uparrow$ \\
\hline Histology & $=$ & $=$ & $=$ & $=$ & $=$ & $\uparrow$ & $\uparrow$ \\
\hline Plasma parameters & $=$ & & & $=$ & $=$ & $=$ & $=$ \\
\hline \multicolumn{8}{|l|}{ Haematopoiesis } \\
\hline Uranium accumulation in bone & & $=$ & & & $\uparrow$ & & $\uparrow$ \\
\hline Bone marrow progenitors & $=$ & & & & $=$ & & $=$ \\
\hline Spleen progenitors & $=$ & & & & $=$ & & $=$ \\
\hline Blood cell counts & $=$ & & & $=$ & $=$ & $=$ & $=$ \\
\hline Plasma cytokines & $=$ & $\downarrow$ & $=$ & $\downarrow$ & $=$ & $=$ & $=$ \\
\hline \multicolumn{8}{|l|}{ Brain } \\
\hline Uranium accumulation & & $=$ & & $=$ & & $=$ & $=$ \\
\hline Antioxidant enzymes & $\downarrow$ & $\downarrow \uparrow$ & & & $\downarrow \uparrow$ & & $\downarrow \uparrow$ \\
\hline Cholinergic pathway & $=\downarrow$ & $=\downarrow$ & & & & $=\downarrow$ & $=\downarrow$ \\
\hline
\end{tabular}

EMX: enzymes and transcription factors of xenobiotic metabolism; Chol Met: enzymes and transcription factors of cholesterol metabolism.

observed in animals contaminated with uranium regardless the uranium level in drinking water. Table 6 summarizes the data obtained in the present study, biological effects and deleterious effects.

Thus, according to standard criteria, we conclude that the NOAEL (No-Observed-Adverse-Effect Level) threshold for uranium chronically ingested in drinking water is superior to $120 \mathrm{mg} / \mathrm{L}$ for male adult rats. The findings of the present study indicate thus that the NOAEL threshold based in the present study on the histological alterations was $>125$ times higher than the level determined in Gilman's study $(>120 \mathrm{mg} / \mathrm{L}$ versus $<0.96 \mathrm{mg} / \mathrm{L}$, resp.).

The guideline issued by WHO (2005) [3] derived with a TDI (tolerable daily intake) approach from Gilman's study (1998) [19] and based on uranium's chemical toxicity to the kidneys assessed a LOAEL of $0.96 \mathrm{mg} / \mathrm{L}$, equivalent to
$0.06 \mathrm{mg} / \mathrm{kg} / \mathrm{day}$. This TDI, combined with a presumed uncertainty factor of 100 and a presumed $60 \mathrm{~kg}$ adult consuming $2 \mathrm{~L}$ of drinking water daily, yielded a guideline value of $15 \mu \mathrm{g} / \mathrm{L}$ (before July 2011). A similar calculation was applied to our results deduced from a $5.4 \mathrm{mg} / \mathrm{kg} /$ day dose ingested by a rat weighting between 300 and $700 \mathrm{~g}$ during the whole experiment and consuming between 20 and $30 \mathrm{~mL}$ of water contaminated at $120 \mathrm{mg} / \mathrm{L}$ (see Figure 1). This calculation leads to a guideline value of $1350 \mu \mathrm{g} / \mathrm{L}$, a very high value compared with environmental levels and the WHO reference guideline. Indeed, WHO established a new guideline value in 2011 based on new epidemiological studies not able to demonstrate obvious effects of uranium below an exposure concentration of $30 \mu \mathrm{g} / \mathrm{L}$ [17]. In fact, changes of proximal tubular function of kidneys remained in the physiological range for the different published epidemiological studies for 
uranium levels $<30 \mu \mathrm{g} / \mathrm{L}$ [18]. Our results seem consistent with epidemiological studies that found no adverse effects in adults exposed to drinking-water containing naturally high uranium levels of 500 to $1000 \mu \mathrm{g} / \mathrm{L}$ [58-61]. Other studies have reported some slight effects on renal function for uranium exposure $>300 \mu \mathrm{g} / \mathrm{L}[62,63]$, effects that did not appear either deleterious or irreversible. The conjunction of experimental and epidemiological studies suggests thus that the threshold for induction of renal adverse effects should at least be above $300 \mu \mathrm{g} / \mathrm{L}$ for humans consuming uraniumcontaminated drinking water. This value was 10 -fold higher that the guideline value of $30 \mu \mathrm{g} / \mathrm{L}$ provided by WHO in 2011 [17].

\section{Conclusions}

In conclusion, TDI calculation leads to a guideline value of $1350 \mu \mathrm{g} / \mathrm{L}$, a very high value compared with WHO reference guideline $(30 \mu \mathrm{g} / \mathrm{L})$. Our experimental results associated with published epidemiological studies suggest that adverse chemical effects of uranium on kidneys in humans should be expected only for values above $300 \mu \mathrm{g} / \mathrm{L}$. In light of these new results, it appears that the current $\mathrm{WHO}$ reference guideline for uranium content in drinking water is very protective $(\times 100)$ and might be reconsidered.

\section{Abbreviations \\ DU: Depleted uranium \\ EMX: Enzymes of xenobiotic metabolism \\ NOAEL: No-Observed-Adverse-Effect Level \\ LOAEL: Low-Observed-Adverse-Effect Level \\ LOEL: Low-Observed-Effect Level \\ TDI: Tolerable daily intake \\ WHO: World Health Organization.}

\section{Conflict of Interests}

The authors declare that there is no conflict of interests regarding the publication of this paper.

\section{Acknowledgments}

The authors thank T. Loiseau and F. Voyer for animal care and J. Briard for management of nuclear sources and wastes. This study was part of the ENVIRHOM research program supported by the "Institut de Radioprotection et de Sûreté Nucléaire (IRSN)" and was also partly funded by the "Delegation Generale de l'Armement" (DGA, France, CER 2006.94.0920).

\section{References}

[1] M. Cuney, "The extreme diversity of uranium deposits," Mineralium Deposita, vol. 44, no. 1, pp. 3-9, 2009.

[2] United Nations Scientific Committee on the Effects of Atomic Radiation (UNSCEAR), Sources and effects of ionizing radiation. Volume I: Sources; Volume II, "Effects. Report to the
General Assembly, with scientific annexes. United Nations sales publications E.00.IX.3 and E.00.IX.4. United Nations", 2000.

[3] WHO (World Health Organization), "Uranium in drinkingwater background document for development of WHO guidelines for drinking-water quality," Tech. Rep., 2005.

[4] B. C. Jurgens, M. S. Fram, K. Belitz, K. R. Burow, and M. K. Landon, "Effects of groundwater development on uranium: Central Valley, California, USA," Ground Water, vol. 48, no. 6, pp. 913-928, 2010.

[5] Province of British Columbia, "Variation in uranium and radioactivity levels in surface and ground water at selected sites in British Columbia, April 1980-March 1981," Tech. Rep., B.C. Ministry of Energy, Mines and Petroleum Resources and B.C. Ministry of Health, Victoria, Canada, 1981.

[6] Z. Pan and L. Senlin, Radiation Level in China, China Atomic Energy Publishing and Media, 2011.

[7] IRSN (Institut de Radioprotection et de Sûreté Nucléaire), "Bilan: la qualité radiologique de l'eau du robinet en France 2008-2009," Tech. Rep., 2011.

[8] K. G. Orloff, K. Mistry, P. Charp et al., "Human exposure to uranium in groundwater," Environmental Research, vol. 94, no. 3, pp. 319-326, 2004.

[9] M. Muikku, T. Heikkinen, M. Puhakainen, T. Rahola, and L. Salonen, "Assessment of occupational exposure to uranium by indirect methods needs information on natural background variations," Radiation Protection Dosimetry, vol. 125, no. 1-4, pp. 492-495, 2007.

[10] O. Prat, T. Vercouter, E. Ansoborlo et al., "Uranium speciation in drinking water from drilled wells in Southern Finland and its potential links to health effects," Environmental Science and Technology, vol. 43, no. 10, pp. 3941-3946, 2009.

[11] F. P. Carvalho and J. M. Oliveira, "Uranium isotopes in the Balkan's environment and foods following the use of depleted uranium in the war," Environment International, vol. 36, no. 4, pp. 352-360, 2010.

[12] A. Frostick, A. Bollhöfer, and D. Parry, "A study of radionuclides, metals and stable lead isotope ratios in sediments and soils in the vicinity of natural U-mineralisation areas in the Northern Territory," Journal of Environmental Radioactivity, vol. 102, no. 10, pp. 911-918, 2011.

[13] L. Pourcelot, B. Boulet, C. Le Corre et al., "Isotopic evidence of natural uranium and spent fuel uranium releases into the environment," Journal of Environmental Monitoring, vol. 13, no. 2, pp. 355-361, 2011.

[14] S. Handley-Sidhu, M. J. Keith-Roach, J. R. Lloyd, and D. J. Vaughan, "A review of the environmental corrosion, fate and bioavailability of munitions grade depleted uranium," The Science of the Total Environment, vol. 408, no. 23, pp. 5690-5700, 2010.

[15] G. L. Diamond, P. E. Morrow, B. J. Panner, R. M. Gelein, and R. B. Baggs, "Reversible uranyl fluoride nephrotoxicity in the Long Evans rat," Fundamental and Applied Toxicology, vol. 13, no. 1, pp. 65-78, 1989.

[16] J. L. Domingo, J. M. Llobet, J. M. Tomas, and J. Corbella, "Acute toxicity of uranium in rats and mice," Bulletin of Environmental Contamination and Toxicology, vol. 39, no. 1, pp. 168-174, 1987.

[17] WHO (World Health Organization), Guidelines for DrinkingWater Quality, 4th edition, 2011.

[18] I. G. Canu, O. Laurent, N. Pires, D. Laurier, and I. Dublineau, "Health effects of naturally radioactive water ingestion: the need for enhanced studies," Environmental Health Perspectives, vol. 119, no. 12, pp. 1676-1680, 2011. 
[19] A. P. Gilman, D. C. Villeneuve, V. E. Secours et al., "Uranyl nitrate: 28-day and 91-day toxicity studies in the spraguedawley rat," Toxicological Sciences, vol. 41, no. 1, pp. 117-128, 1998.

[20] I. Dublineau, L. Grandcolas, S. Grison et al., "Modifications of inflammatory pathways in rat intestine following chronic ingestion of depleted uranium," Toxicological Sciences, vol. 98, no. 2, pp. 458-468, 2007.

[21] P. Houpert, S. Frelon, P. Lestaevel, C. Bussy, P. Gourmelon, and F. Paquet, "Parental exposure to enriched uranium induced delayed hyperactivity in rat offspring," NeuroToxicology, vol. 28, no. 1, pp. 108-113, 2007.

[22] P. Lestaevel, C. Bussy, F. Paquet et al., "Changes in sleep-wake cycle after chronic exposure to uranium in rats," Neurotoxicology and Teratology, vol. 27, no. 6, pp. 835-840, 2005.

[23] M. Souidi, Y. Gueguen, C. Linard et al., "In vivo effects of chronic contamination with depleted uranium on CYP3A and associated nuclear receptors PXR and CAR in the rat," Toxicology, vol. 214, no. 1-2, pp. 113-122, 2005.

[24] I. Dubuneau, S. Grison, C. Baudelin et al., "Absorption of uranium through the entire gastrointestinal tract of the rat," International Journal of Radiation Biology, vol. 81, no. 6, pp. 473$482,2005$.

[25] H. Berradi, J.-M. Bertho, N. Dudoignon et al., "Renal anemia induced by chronic ingestion of depleted uranium in rats," Toxicological Sciences, vol. 103, no. 2, pp. 397-408, 2008.

[26] C. Floren, L. Tekaya, F. Escaig, L. Labejof, G. Mouthon, and P. Galle, "Analytical microscopy observations of rat enterocytes after oral administration of soluble salts of lanthanides, actinides and elements of group III-A of the periodic chart," Cellular and Molecular Biology, vol. 47, no. 3, pp. 419-425, 2001.

[27] I. Dublineau, S. Grison, L. Grandcolas et al., "Absorption, accumulation and biological effects of depleted uranium in Peyer's patches of rats," Toxicology, vol. 227, no. 3, pp. 227-239, 2006.

[28] K. M. Dias da Cunha, H. Henderson, B. M. Thomson, and A. A. Hecht, "Ground water contamination with $238 \mathrm{U}, 234 \mathrm{U}$, $235 \mathrm{U}, 226 \mathrm{Ra}$ and $210 \mathrm{~Pb}$ from past uranium mining: cove wash, Arizona," Environmental Geochemistry and Health, 2013.

[29] R. Juntunen, "Etelä-Suomen kallioporakaivojen uraanija radontukimukset (Uranium and radon in wells drilled into bedrock in southern Finland. Report of Investigation," Geological Survey of Finland, vol. 98, 1991.

[30] P. Lestaevel, E. Romero, B. Dhieux et al., "Different pattern of brain pro-/anti-oxidant activity between depleted and enriched uranium in chronically exposed rats," Toxicology, vol. 258, no. 1, pp. 1-9, 2009.

[31] C. Rouas, M. Souidi, L. Grandcolas et al., "Acetaminophen induces xenobiotic-metabolizing enzymes in rat: impact of a uranium chronic exposure," Environmental Toxicology and Pharmacology, vol. 28, no. 3, pp. 363-369, 2009.

[32] S. Grison, G. Favé, M. Maillot et al., "Metabolomics identifies a biological response to chronic low-dose natural uranium contamination in urine samples," Metabolomics, vol. 9, no. 6, pp. 1168-1180, 2013.

[33] M. Prat, C. Demarquay, J. Frick, N. Dudoignon, D. Thierry, and J. M. Bertho, "Use of Flt3 ligand to evaluate residual hematopoiesis after heterogeneous irradiation in mice," Radiation Research, vol. 166, no. 3, pp. 504-511, 2006.

[34] T. J. Fry and C. L. Mackall, "The many faces of IL-7: from lymphopoiesis to peripheral T cell maintenance," Journal of Immunology, vol. 174, no. 11, pp. 6571-6576, 2005.
[35] N. Brink, M. Szamel, A. R. Young, K. P. Wittern, and J. Bergemann, "Comparative quantification of IL-1 $\beta$, IL-10, IL-10r, TNF $\alpha$ and IL-7 mRNA levels in UV-irradiated human skin in vivo," Inflammation Research, vol. 49, no. 6, pp. 290-296, 2000.

[36] C. Rouas, J. Stefani, S. Grison et al., "Effect of nephrotoxic treatment with gentamicin on rats chronically exposed to uranium," Toxicology, vol. 279, no. 1-3, pp. 27-35, 2011.

[37] M. Souidi, M. Parquet, J. Férézou, and C. Lutton, "Modulation of cholesterol $7 \alpha$-hydroxylase and sterol 27 -hydroxylase activities by steroids and physiological conditions in hamster," Life Sciences, vol. 64, no. 17, pp. 1585-1593, 1999.

[38] H. Bensoussan, L. Grandcolas, B. Dhieux-Lestaevel et al., "Heavy metal uranium affects the brain cholinergic system in rat following sub-chronic and chronic exposure," Toxicology, vol. 261, no. 1-2, pp. 59-67, 2009.

[39] K. Jomova, D. Vondrakova, M. Lawson, and M. Valko, "Metals, oxidative stress and neurodegenerative disorders," Molecular and Cellular Biochemistry, vol. 345, no. 1-2, pp. 91-104, 2010.

[40] I. Q. Whishaw, W. T. O'Connor, and S. B. Dunnett, "Disruption of central cholinergic systems in the rat by basal forebrain lesions or atropine: effects on feeding, sensorimotor behaviour, locomotor activity and spatial navigation," Behavioural Brain Research, vol. 17, no. 2, pp. 103-115, 1985.

[41] N. M. Wade-Gueye, O. Delissen, P. Gourmelon, J. Aigueperse, I. Dublineau I, and M. Souidi, "Chronic exposure to natural uranium via drinking water affects bone in growing rats," Biochimica et Biophysica Acta, vol. 1820, no. 7, pp. 1121-1127, 2012.

[42] R. Racine, L. Grandcolas, S. Grison et al., "Cholesterol $7 \alpha$ hydroxylase (CYP7A1) activity is modified after chronic ingestion of depleted uranium in the rat," The Journal of Steroid Biochemistry and Molecular Biology, vol. 120, no. 1, pp. 60-66, 2010.

[43] V. Linares, M. Bellés, M. L. Albina, J. J. Sirvent, D. J. Sánchez, and J. L. Domingo, "Assessment of the pro-oxidant activity of uranium in kidney and testis of rats," Toxicology Letters, vol. 167, no. 2, pp. 152-161, 2006.

[44] V. Linares, D. J. Sánchez, M. Bellés, L. Albina, M. Gómez, and J. L. Domingo, "Pro-oxidant effects in the brain of rats concurrently exposed to uranium and stress," Toxicology, vol. 236, no. 1-2, pp. 82-91, 2007.

[45] W. Briner and J. Murray, "Effects of short-term and long-term depleted uranium exposure on open-field behavior and brain lipid oxidation in rats," Neurotoxicology and Teratology, vol. 27, no. 1, pp. 135-144, 2005.

[46] C. Bussy, P. Lestaevel, B. Dhieux et al., "Chronic ingestion of uranyl nitrate perturbs acetylcholinesterase activity and monoamine metabolism in male rat brain," NeuroToxicology, vol. 27, no. 2, pp. 245-252, 2006.

[47] M. L. Albina, M. Bellés, V. Linares, D. J. Sánchez, and J. L. Domingo, "Restraint stress does not enhance the uraniuminduced developmental and behavioral effects in the offspring of uranium-exposed male rats," Toxicology, vol. 215, no. 1-2, pp. 69-79, 2005.

[48] F. Paquet, P. Houpert, E. Blanchardon et al., "Accumulation and distribution of uranium in rats after chronic exposure by ingestion," Health Physics, vol. 90, no. 2, pp. 139-147, 2006.

[49] É. Arnault, M. Doussau, A. Pesty et al., "Natural uranium disturbs mouse folliculogenesis in vivo and oocyte meiosis in vitro," Toxicology, vol. 247, no. 2-3, pp. 80-87, 2008.

[50] A. Feugier, S. Frelon, P. Gourmelon, and M. Claraz, "Alteration of mouse oocyte quality after a subchronic exposure to depleted 
Uranium," Reproductive Toxicology, vol. 26, no. 3-4, pp. 273-277, 2008.

[51] P. Grandjean and P. Landrigan, "Developmental neurotoxicity of industrial chemicals," The Lancet, vol. 368, no. 9553, pp. 21672178, 2006.

[52] S. Raymond-Whish, L. P. Mayer, T. O’Neal et al., "Drinking water with uranium below the U.S. EPA water standard causes estrogen receptor-dependent responses in female mice," Environmental Health Perspectives, vol. 115, no. 12, pp. 1711-1716, 2007.

[53] J. P. Myers, R. T. Zoeller, and F. S. Vom Saal, "A clash of old and new scientific concepts in toxicity, with important implications for public health," Environmental Health Perspectives, vol. 117, no. 11, pp. 1652-1655, 2009.

[54] I. Sabolić, "Common mechanisms in nephropathy induced by toxic metals," Nephron-Physiology, vol. 104, no. 3, pp. p107p114, 2006.

[55] A. Ortega, J. L. Domingo, J. M. Llobet, J. M. Tomas, and J. L. Paternain, "Evaluation of the oral toxicity of uranium in a 4week drinking-water study in rats," Bulletin of Environmental Contamination and Toxicology, vol. 42, no. 6, pp. 935-941, 1989.

[56] S. Homma-Takeda, T. Kokubo, Y. Terada et al., "Uranium dynamics and developmental sensitivity in rat kidney," Journal of Applied Toxicology, vol. 33, no. 7, pp. 685-694, 2013.

[57] S. Frelon, P. Houpert, D. Lepetit, and F. Paquet, "The chemical speciation of uranium in water does not influence its absorption from the gastrointestinal tract of rats," Chemical Research in Toxicology, vol. 18, no. 7, pp. 1150-1154, 2005.

[58] P. Kurttio, A. Harmoinen, H. Saha et al., "Kidney toxicity of ingested uranium from drinking water," American Journal of Kidney Diseases, vol. 47, no. 6, pp. 972-982, 2006.

[59] A. I. Seldén, C. Lundholm, B. Edlund et al., "Nephrotoxicity of uranium in drinking water from private drilled wells," Environmental Research, vol. 109, no. 4, pp. 486-494, 2009.

[60] H. S. Magdo, J. Forman, N. Graber et al., "Grand rounds: nephrotoxicity in a young child exposed to uranium from contaminated well water," Environmental Health Perspectives, vol. 115, no. 8, pp. 1237-1241, 2007.

[61] P. Kurttio, A. Auvinen, L. Salonen et al., "Renal effects of uranium in drinking water," Environmental Health Perspectives, vol. 110, no. 4, pp. 337-342, 2002.

[62] M. Limson Zamora, B. L. Tracy, J. M. Zielinski, D. P. Meyerhof, and M. A. Moss, "Chronic ingestion of uranium in drinking water: a study of kidney bioeffects in humans," Toxicological Sciences, vol. 43, no. 1, pp. 68-77, 1998.

[63] M. L. L. Zamora, J. M. Zielinski, G. B. Moodie, R. A. F. Falcomer, W. C. Hunt, and K. Capello, "Uranium in drinking water: renal effects of long-term ingestion by an aboriginal community," Archives of Environmental \& Occupational Health, vol. 64, no. 4, pp. 228-241, 2009. 

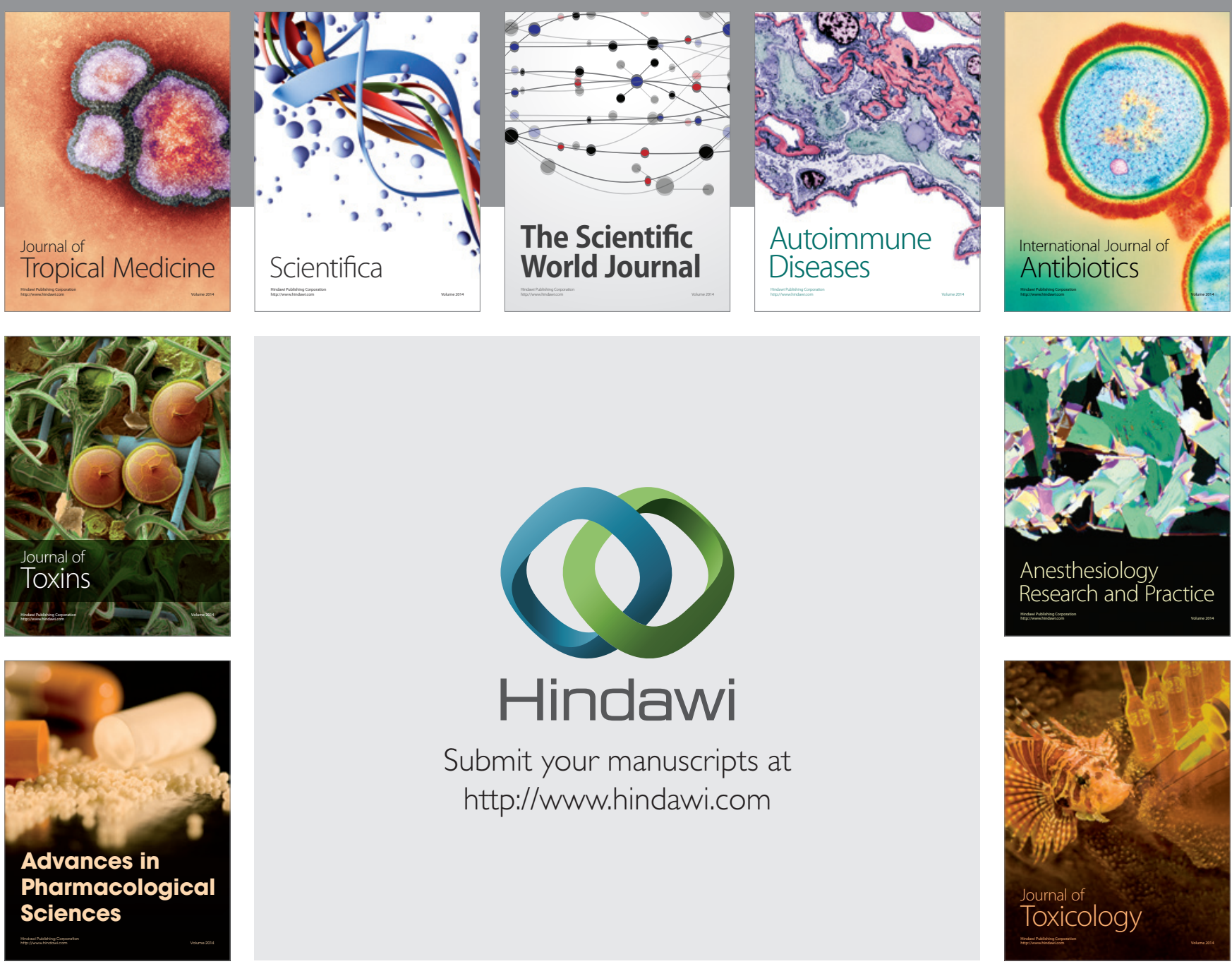

\section{Hindawi}

Submit your manuscripts at

http://www.hindawi.com
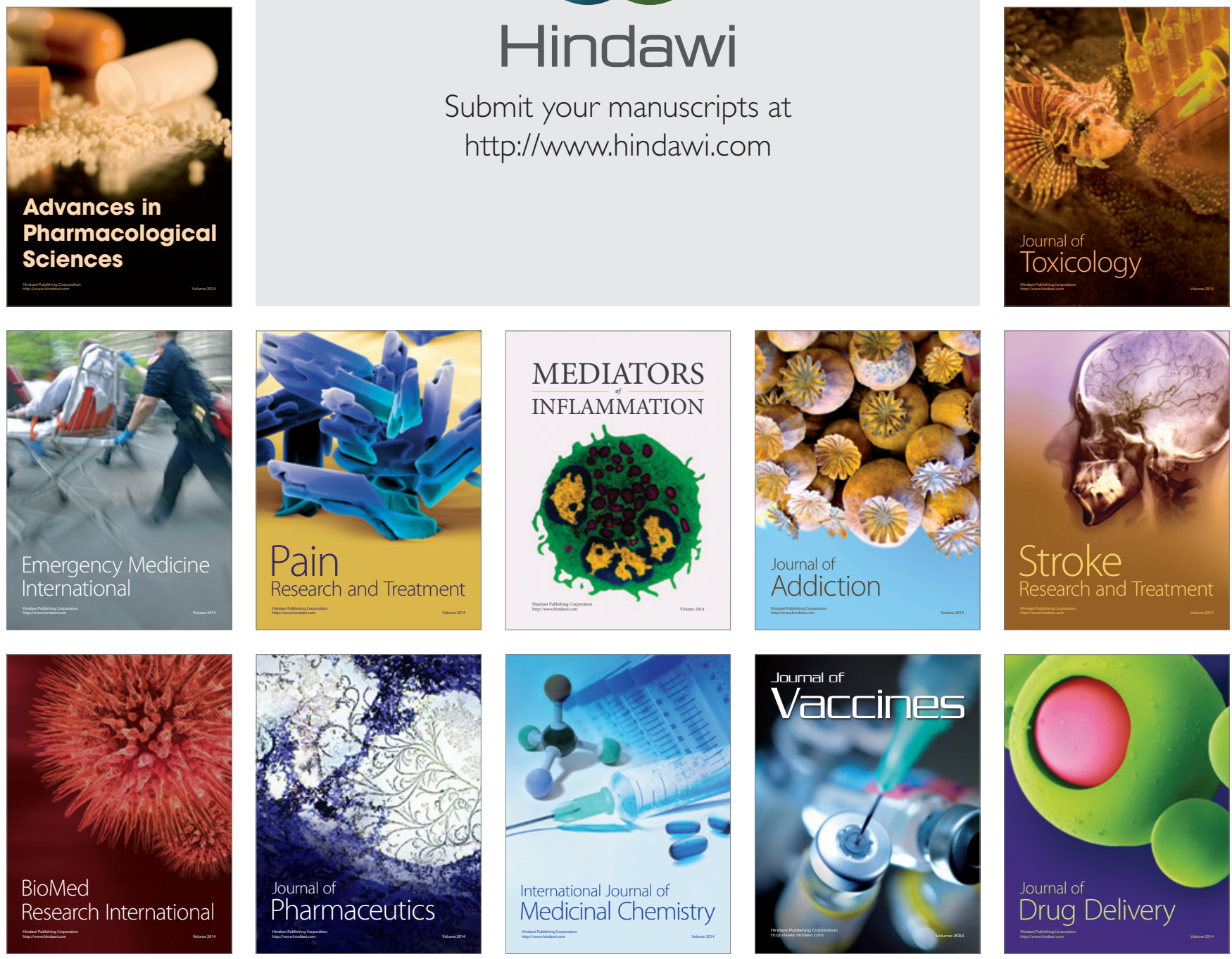